\title{
Hepatocellular Carcinoma Immune Landscape and the Potential of Immunotherapies
}

\author{
Julie Giraud ${ }^{1}$, Domitille Chalopin ${ }^{1}$, Jean-Frédéric Blanc ${ }^{2,3}$ and Maya Saleh ${ }^{1,4 *}$ \\ ${ }^{1}$ University of Bordeaux, CNRS, ImmunoConcEpT, UMR 5164, Bordeaux, France, ${ }^{2}$ University of Bordeaux, INSERM UMR \\ 1053, Bordeaux, France, ${ }^{3}$ Department of Oncology, CHU Bordeaux, Haut Leveque Hospital, Pessac, France, ${ }^{4}$ Department \\ of Medicine, McGill University, Montreal, QC, Canada
}

Hepatocellular carcinoma ( $\mathrm{HCC})$ is the most common liver tumor and among the deadliest cancers worldwide. Advanced HCC overall survival is meager and has not improved over the last decade despite approval of several tyrosine kinase inhibitors (TKi) for first and second-line treatments. The recent approval of immune checkpoint inhibitors (ICl) has revolutionized HCC palliative care. Unfortunately, the majority of HCC patients fail to respond to these therapies. Here, we elaborate on the immune landscapes of the normal and cirrhotic livers and of the unique HCC tumor microenvironment. We describe

OPEN ACCESS

Edited by:

Frank Tacke,

Charité-Universitätsmedizin Berlin, Germany

Reviewed by: Wiebke Werner

Charité-Universitätsmedizin Berlin, Germany Suchira Gallage,

German Cancer Research Center (DKFZ), Germany

*Correspondence: Maya Saleh maya.saleh@u-bordeaux.fr

Specialty section:

This article was submitted to Cancer Immunity and Immunotherapy,

a section of the journal

Frontiers in Immunology

Received: 19 January 2021 Accepted: 22 February 2021

Published: 18 March 2021

Citation:

Giraud J, Chalopin D, Blanc J-F and Saleh M (2021) Hepatocellular Carcinoma Immune Landscape and the Potential of Immunotherapies.

Front. Immunol. 12:655697. doi: 10.3389/fimmu.2021.655697 the molecular and immunological classifications of HCC, discuss the role of specific immune cell subsets in this cancer, with a focus on myeloid cells and pathways in antitumor immunity, tumor promotion and immune evasion. We also describe the challenges and opportunities of immunotherapies in HCC and discuss new avenues based on harnessing the anti-tumor activity of myeloid, NK and $\gamma \delta T$ cells, vaccines, chimeric antigen receptors (CAR)-T or -NK cells, oncolytic viruses, and combination therapies.

Keywords: immunotherapy, immune checkpoint inhibitors, tumor microenvironment, tumor-associated macrophages, immunosuppression, inflammation, cirrhosis, NASH

\section{PREFACE}

The liver is a critical hub of metabolism, glucose storage, lipid and cholesterol homeostasis, detoxification and processing of xenobiotics, endocrine regulation of growth signaling, blood volume regulation, and immune surveillance. These essential functions are coordinated by multiple cell types: the hepatocytes, which make up $80 \%$ of the liver volume; the cholangiocytes, which line the biliary ducts and are the second most abundant parenchymal cells of the liver; the liver sinusoidal endothelial cells (LSECs), which line the hepatic sinusoidal walls and display specialized functions in scavenging, antigen presentation and leukocyte recruitment [reviewed in (1)]; the hepatic stellate cells (HSCs), the body's largest storage site of vitamin A at quiescent state; and the liver-resident immune cells, which are particularly enriched in this important immune organ. The liver is continuously challenged with microbial- and danger-associated molecular patterns (MAMPs and DAMPs) and non-self-peptides derived from dietary and gut-derived microbial antigens. Its capacity to deal with these insults is reflected by its particular immune environment. Indeed, the liver hosts the largest population of tissue-resident macrophages, known as Kupffer cells (KCs). It also exhibits a high frequency of tissue-resident lymphocytes, namely natural killer (NK) cells, NKT cells, conventional $\alpha \beta$ T cells, unconventional $\gamma \delta$ T cells and B cells. The liver's diverse immunotolerance mechanisms limit the development of chronic liver diseases, including cirrhosis and liver cancers. 
Hepatocellular carcinoma (HCC), which accounts for approximately $90 \%$ of the incidence of all primary liver cancers, is the 5th most prevalent cancer worldwide and the 4th leading cause of death globally (2). Both environmental and genetic risk factors contribute to the etiology of HCC. The most notable environmental and potentially preventable risk factors include oncogenic virus infection with hepatitis $B$ virus $(\mathrm{HBV})$ or hepatitis $\mathrm{C}$ virus (HCV), alcohol abuse, and the metabolic syndrome related to obesity and diabetes mellitus [reviewed in (3)]. In addition, some rare monogenic diseases and several single nucleotide polymorphisms (SNPs) predispose individuals to HCC [reviewed in (4)] (Figure 1A). HCC incidence has doubled in the last three decades in the US, presumably due to high prevalence of HCV infection in the mid 1900's and increasing obesity-related non-alcoholic fatty liver disease (NAFLD) progressing to non-alcoholic steatohepatitis (NASH). Accordingly, suppression of $\mathrm{HBV} / \mathrm{HCV}$ infections may improve HCC clinical outcomes, but few patients with HCC are cured of their hepatic infections due to treatment cost, compliance and toxicity issues, and NAFLD is expected to become the major risk factor for developing HCC in developed countries in the near future (5). In very early or early-stage HCC (stage 0/A, according to the Barcelona Clinic Liver Cancer [BCLC] staging system), the most effective therapeutic option remains surgical resection, liver transplantation or percutaneous local ablation. In this early stage, the median overall survival (mOS) is $>60$ months with a 5 -year survival of $60-80 \%$, but the 5 -year recurrence rate is up to $70 \%$ [reviewed in (6)]. However, the large majority of HCCs are diagnosed at an intermediate (stage B) or an advanced stage (stage C), when the mOS is $\sim 11-20$ months with a 5-year survival of $16 \%$.

The therapeutic options for these stages are limited to locoregional treatments, including transarterial chemoembolization (TACE) or radioembolization with yttrium 90 (90Y)-microspheres, and systemic treatment with multi

Abbreviations: ACT, adoptive cell therapy; ADCC, antibody-dependent cell cytotoxicity; BCLC, Barcelona Clinic Liver Cancer; CAR, chimeric antigen receptors; DAMPs, danger-associated molecular patterns; EC, endothelial cells; ECM, extracellular matrix; EMT, epithelial-to-mesenchymal transition; fDC, follicular dendritic cell; HBV, hepatitis B virus; HCC, hepatocellular carcinoma; HCV, hepatitis C virus; HSC, hepatic stellate cells; ICI, immune checkpoint inhibitor; IFNg, interferon gamma; IHC, immunohistochemistry; ILCs, innate lymphoid cells; IKC, immune killer cells; irAEs, immune-related adverse events; KC, Kupffer cells; LIHC, liver hepatocellular carcinoma; LSEC, liver sinusoidal endothelial cells; MAGE-A, melanoma antigen gene A; MAMPs, microbialassociated molecular patterns; MAPK, mitogen-activated protein kinase; MDSCs, myeloid-derived suppressor cells; MNPs, mononuclear phagocytes; mOS, median overall survival; mregDCs, mature DCs enriched in immunoregulatory molecules; mTOR, mammalian target of rapamycin; NK cells, natural killer cells; cNK cells, conventional NK cells; LrNK cells, liver-resident NK cells; NKT cells, natural killer T cells; NSCLC, non-small cell lung cancer; ORR, overall response rate; pDC, plasmacytoïd dentritic cells; PFS, progression-free survival; $\mathrm{PI}(3) \mathrm{K}$, Phosphoinositide 3-kinase; RTK, receptor tyrosine kinase; SART, squamous cell carcinoma antigen recognized by T cells; scRNAseq, single cell RNA sequencing; SNPs, single nucleotide polymorphisms; TAA, tumor-associated antigens; TACE, transarterial chemo-embolization; TAMs, tumor-associated macrophages; TCR, T-cell receptor; Tex, exhausted T cells; TIC, tumor-initiating cells; TILs, tumorinfiltrating lymphocytes; TKi, tyrosine kinase inhibitors; TLS, tertiary lymphoid structures; TME, tumor microenvironment; Treg, regulatory T cells; TSA, tumorspecific antigens. tyrosine kinase inhibitors (TKi), such as Sorafenib (7) or Lenvatinib (8), according to international guidelines (9). While approved as a first-line therapy, these TKi improve mOS by 3 months $(7,8,10)$ and are associated with significant side effects (11). In patients that progress following first line TKi treatment, the second-line options have been, until recently, alternative $\mathrm{TKi}$, primarily regorafenib (12) and cabozantinib (13), or the fully human monoclonal antibody targeting vascular-endothelial growth factor (VEGF) receptor type 2 (VEGF-R2) ramucirumab (14). More recently, immune checkpoint inhibitors (ICI) have emerged as an alternative therapy in HCC and two anti-PD-1 drugs, nivolumab and pembrolizumab, have been approved in the USA based on two trials $(15,16)$ as a second line treatment for patients with advanced HCC refractory to sorafenib. The overall response rate (ORR) of nivolumab was reported to be $23 \%$ in sorafenib-naïve patients and $16-19 \%$ in sorafenibexperienced patients, with a mOS of 15 months. However, this did not reproduce in the phase III trial checkmate 459, in which the ORR to nivolumab in sorafenib-naïve patients was $15 \%$, with a mOS of 16 months, i.e., not different from that with sorafenib. Further, in a recent trial, pembrolizumab monotherapy did not statistically impact HCC patients mOS and progression-free survival (PFS), as a second-line treatment (17). The combination of Regorafenib (angiogenesis inhibitor) and nivolumab has next been proposed as a second line treatment in sorafenib non-responders. This year, the combination of atezolizumab (anti-PD-L1) and bevacizumab (anti-VEGF) has obtained approval as a new first line therapy, as it improved mOS > 17 months (18) (Figure 1B). However, despite this therapeutic advance, $\sim 75 \%$ of HCC patients do not respond to these immunotherapies for unclear reasons. While there is evidence that boosting the activity of tumor-specific T cells might benefit patients with HCC, the underlying chronic inflammation renders this cancer's tumor microenvironment (TME) somewhat unique, and highlights the urgent need to further explore this organ-specific immunity, identify biomarkers to select patients who are likely to respond to such treatments, and develop new immunotherapies combinations.

\section{THE LANDSCAPE OF PARENCHYMAL, STROMAL AND IMMUNE CELLS IN THE HEALTHY VS. CIRRHOTIC LIVER}

Prior to delving into the immune landscape and immunosuppressive mechanisms of HCC, we briefly overview the architecture of the liver and its immune system under physiological conditions, and highlight specific changes occurring in cirrhosis. Anatomically, the human liver is composed of eight functional segments organized into hepatic lobules containing their portal vein, hepatic artery and bile duct triads (Figure 2A). Around $80 \%$ of the blood supply is delivered from the gut via the portal vein, while the remaining $20 \%$ flows through the hepatic artery. Upon mixing, the blood equilibrates and drains across the lobule through the hepatic sinusoids into the central veins, while the bile flows in the opposite direction via bile canaliculi. Such an organization creates oxygen and 
A

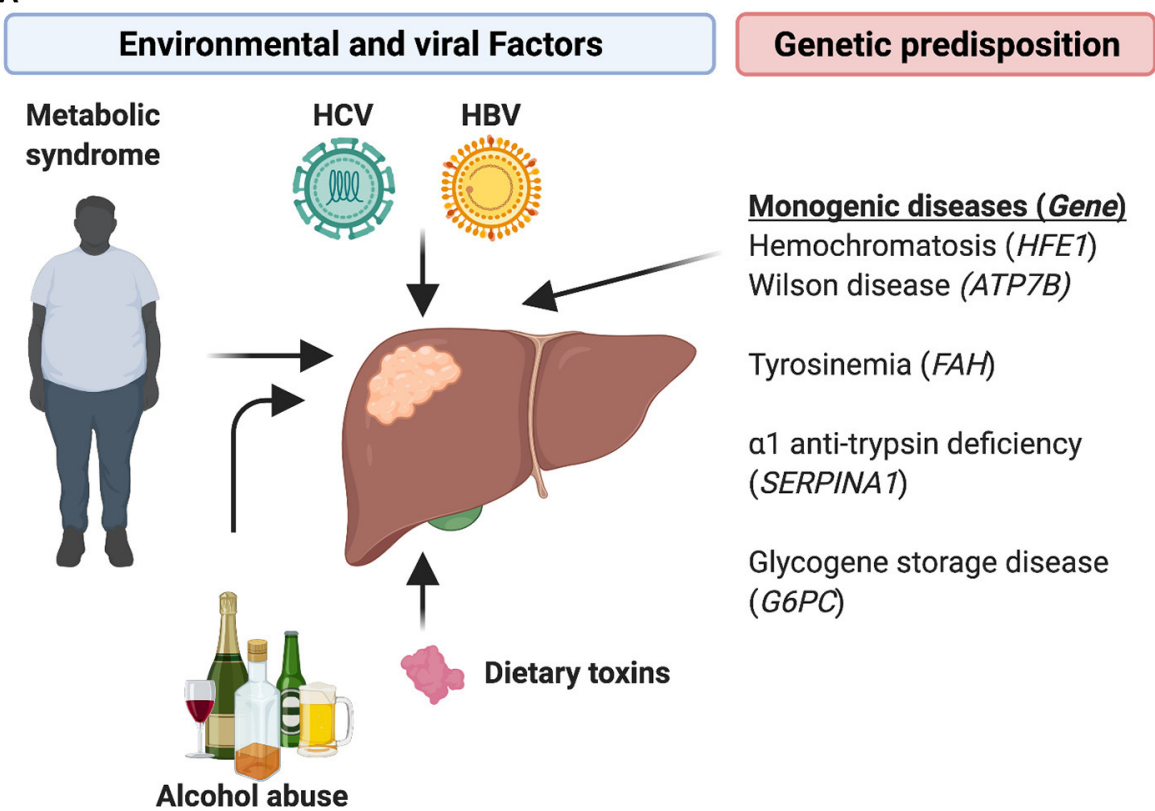

B

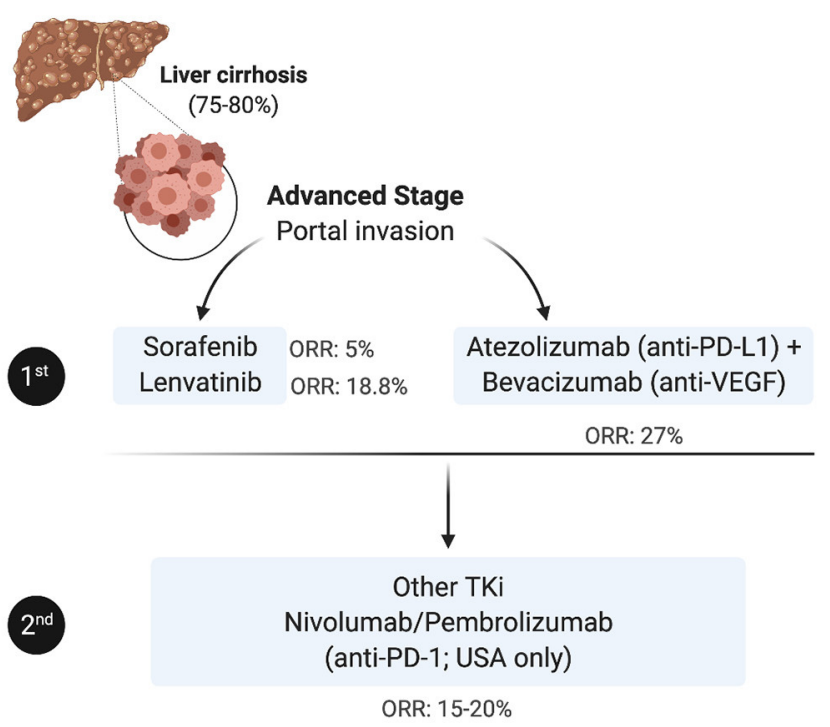

FIGURE 1 | HCC etiologies, genetic predisposition and current standard of care for the advanced stage. (A) HCC etiologies include chronic infection with HBV or $\mathrm{HCV}$, alcohol abuse, dietary toxins and/or the metabolic syndrome linked to obesity and type 2 diabetes. In rare cases, HCC stems from a monogenic disease e.g. hemochromatosis, caused by mutations in the homeostatic iron regulator gene HFE1; Wilson disease involving mutations in the ATPase copper transporting beta gene ATP7B; tyrosinemia, resulting from mutations in the gene encoding fumarylacetoacetate hydrolase FAH, $\alpha 1$-trypsin deficiency caused by mutations in serpin family A member 1 SERPINA1; or glycogen storage disease, in which the glucose-6-phosphatase gene is mutated. (B) The standard of care for treating patients with advanced HCC has been revised with the approval of immune checkpoint inhibitors. In first line, patients are administered TKi, mainly sorafenib or lenvatinib, or given the newly approved combination of bevacizumab (anti-VEGF) + atezolizumab (anti-PD-L1). In second line, patients refractory to TKi are treated with other TKIs, whereas anti-PD-1 ICl, nivolumab or pembrolizumab, have only been approved in the USA as an option for second line (despite the lack of superior efficacity in phase III trials compared to TKi).

metabolic gradients, referred to as liver zonation, controlled in part by $\mathrm{WNT} / \beta$-catenin signaling (Figure 2B). Liver sinusoids are lined by a fenestrated monolayer of LSECs that lack a basement membrane, allowing the blood to directly reach the underlying hepatocytes, organized in two-layered plates. The luminal side of LSECs interacts with liver resident immune cells, such as KCs, whereas their basal side, facing the space of Disse, interacts with hepatocytes and HSCs (Figure 2C). The liver has 
A

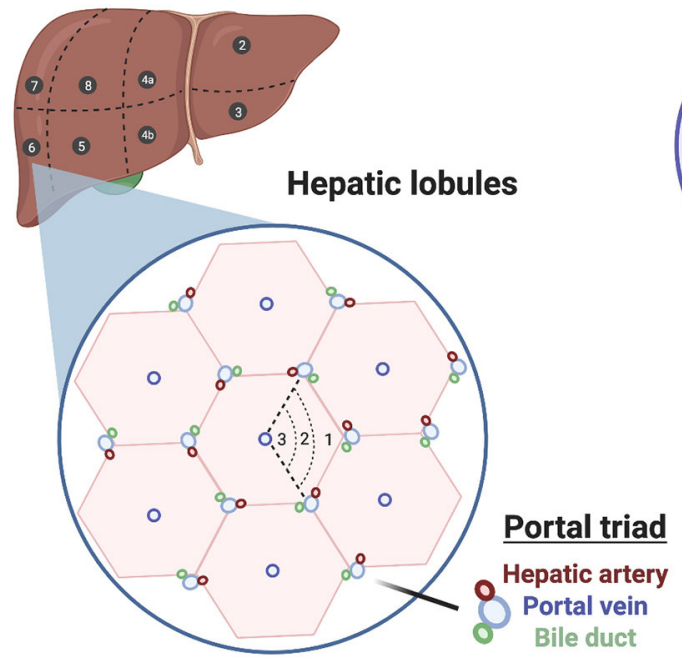

B
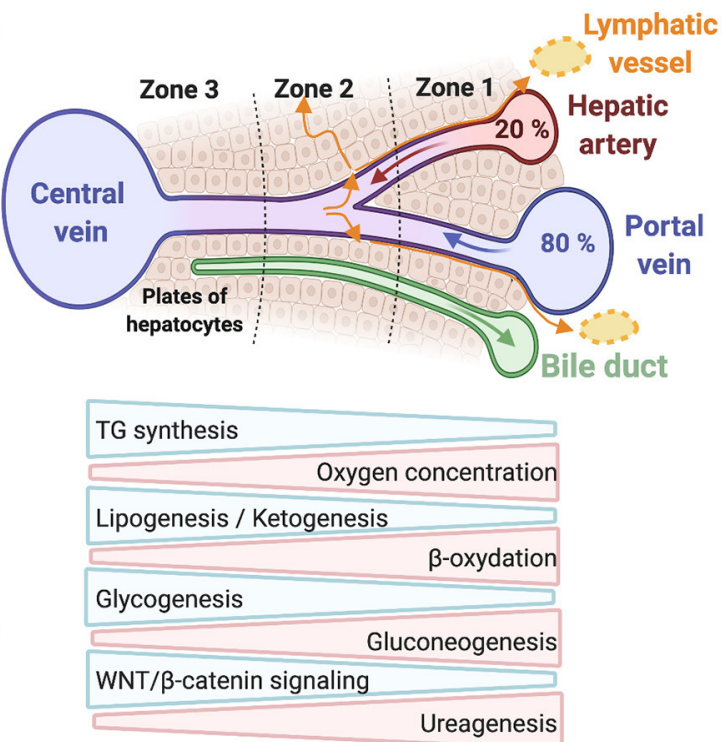

C

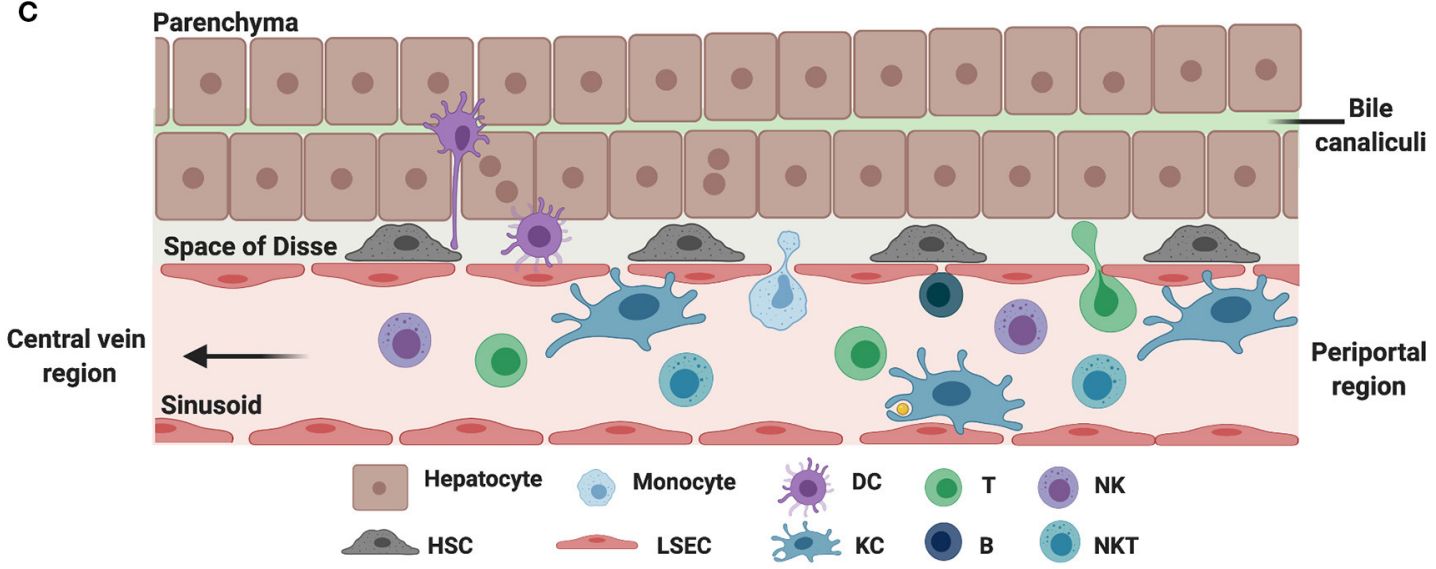

FIGURE 2 | Architecture of the human liver and its immune system. (A) Schematic illustration of the human liver anatomy namely its 8 segments, hepatic lobules, and triads of portal vein/hepatic artery/bile duct. (B) The liver zonation. Oxygen and metabolic gradients define three liver zones with specialized hepatocytes functions. (C) A zoom on hepatic cellular interactions across the sinusoids, the space of Disse and the hepatocyte plates. Liver sinusoidal endothelial cells (LSECs) line the liver sinusoid by forming a fenestrated monolayer. Their basal side interacts with hepatocytes and hepatic stellate cells (HSCs) in the space of Disse, whereas their luminal side interacts with liver-resident leukocytes, including Kupffer cells (KCs).

long been considered as a site of immune tolerance. This was based on early findings that transplanted allogeneic liver was significantly better tolerated than other organs, and patients required low levels of immunosuppression [reviewed in (19)]. Liver immune tolerance stems from complex interactions among liver-resident cells and peripheral leukocytes, and involves poor or incomplete activation of $\mathrm{CD} 4^{+}$and $\mathrm{CD} 8^{+} \mathrm{T}$ cells, elevated expression of immune checkpoints and an immunosuppressive environment mediated by IL-10 and TGF $\beta$ [reviewed in (20)]. KCs that function to preserve tissue homeostasis through their phagocytic and antigen presentation activity are important players in maintaining immune tolerance. Interestingly, a recent paper from the Germain group unraveled that microbiota sensing by LSECs imposes a chemokine gradient around the portal triads resulting in discriminate abundance of KCs and other immune cells (e.g., NKT cells) in periportal regions. Functionally, such an "immune zonation" is critical in limiting local infection and associated inflammatory tissue damage and in preventing the systemic spread of bacteria (21). Besides KCs, hepatic NK cells are capable of directly killing stressed cells, and mediate antibody-dependent cell cytotoxicity (ADCC) upon engagement of CD16 (Fc $\gamma$ RIIIA). Their activity is regulated by a dynamic equilibrium between activating [NKG2D, NKp46 (NCR1), NKp44 (NCR2), and NKp30 (NCR3)] and inhibitory (KIR and NKG2A) receptors. In addition to producing various cytokines, chemokines, and growth factors, they maintain 
immune tolerance through expression of immune checkpoints. Liver-resident NK cells (LrNK) differ from conventional NK (cNK) cells with respect to their origin, phenotypes and functions. Notably, LrNK cells share functional properties with innate lymphoid cells (ILCs) commonly found in mucosal tissues. NKT cells, which also express the NK cell marker CD56, actively patrol the liver and contribute to the clearance of pre-malignant senescent hepatocytes (22). They are recruited via the chemokine receptor CXCR6 interacting with CXCL16, secreted by LSECs and KCs, and are activated upon engagement of the glycolipid receptor CD1d. Last, CD19 ${ }^{+}$B cells exert their functions through antibody production, antigen presentation and immune cell regulation.

Liver injury, caused by viral infection or chronic steatohepatitis related to alcohol or metabolic disorders, triggers an inflammatory cell death, leading to DAMP release and the influx of immune cells. Chronic inflammation activates HSCs, the main actors in liver fibrosis that produce extracellular matrix (ECM) components, forming the so-called "scar tissue." Liver cirrhosis, which affects $1 \%$ of the world population, represents the soil where most HCC cases develop. Indeed, continuous cellular stress, repetitive cycles of necrosis and compensatory regeneration of parenchymal cells and chronic inflammation elicit cellular senescence and mutagenesis leading eventually to HCC development. Furthermore, a reduction of sinusoid porosity (defenestration), associated with collagenization of the space of Disse, was shown to impede immunosurveillance [reviewed in (23)].

The recent use of high-dimensional single cell approaches (e.g., mass cytometry and single cell RNA sequencing [scRNAseq]) in humans has unraveled the cellular landscape of the healthy $(24,25)$ and cirrhotic (26) livers and uncovered subtype heterogeneity for all major liver populations. According to two reports by Aizarani et al. (24) and MacParland et al. (25), in which parenchymal and non-parenchymal cells from dissociated human normal liver tissue were analyzed, the healthy liver is predominantly populated by leukocytes, which make up $45 \%$ of all liver cells, out-numbering hepatocytes (ALB ${ }^{\text {high }}$ ) that account for $\sim 35 \%$ of the cells in this organ. This is followed by endothelial cells, including LSECs (CD34 ${ }^{-}$ $\mathrm{CLEC}_{4}{ }^{+} \mathrm{CLEC} \mathrm{M}^{+}$) and macrovascular endothelial cells

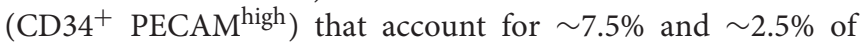
hepatic cells, respectively. HSCs $\left(\mathrm{RGS}^{+}{ }^{+} \mathrm{ACTA}^{+}\right.$) are found at $<1 \%$ of the cells in this organ whereas cholangiocytes $\left(\mathrm{EPCAM}^{+}\right.$ KRT19 $9^{\text {high }} \mathrm{CTFR}^{\text {high }}$ ALB $^{\text {low }}$ ) occupy $\sim 9 \%$ of the liver cellular landscape $(24,25)$ (Figure 3). Interestingly, among the EpCAM ${ }^{+}$ cholangiocytes, a putative bipotent liver progenitor population was identified by Aizarani et al. (24) based on the expression of intermediate levels of the intracellular calcium signal transducer TACTSD2/TROP2 (TROP2 ${ }^{\text {int }}$ ). This population was shown to give rise to $\mathrm{ASGR}^{+}$hepatocyte-biased cells (TROP2 ${ }^{\text {low }}$ ) or KRT19 ${ }^{\text {high }}$ CFTR $^{\text {high }}$ ALB $^{\text {low }}$ cholangiocytes (TROP2 ${ }^{\text {hi }}$ (24). Furthermore, to model liver zonation, Aizarani et al. (24) applied diffusion pseudotime analysis and showed that hepatocytes and LSECs gene expression is highly zonated. LSECs in the periportal zone expressed genes involved in hormone signaling and metabolism, whereas pericentral and mid zone LSECs and hepatocytes were enriched in gene expression related to platelet activation, immune regulation and scavenging.

Among the leukocytes, the ratio of lymphocytes to mononuclear phagocytes (MNPs) is 3:1, with the former occupying $\sim 35 \%$ and the latter $10 \%$ of total liver cells. The lymphocytic compartment includes $\sim 11 \% \alpha \beta \mathrm{T}$ cells, $\sim 6.7 \%$ $\gamma \delta \mathrm{T}$ cells, $\sim 12.3 \% \mathrm{NK}+\mathrm{NKT}$ cells, and $\sim 5 \%$ B cells $(25)$. Among the innate immune cells, NK cells cluster in three groups,

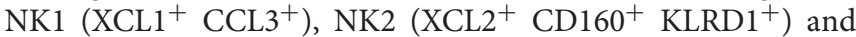
cytotoxic NKs $\left(\mathrm{GNLY}^{+} \mathrm{FGFBP}^{+} \mathrm{SPON}^{+}\right)$, whereas MNPs consist of three subsets, including two $\mathrm{CD}^{+} 8^{+} \mathrm{KC}$ clusters, $\mathrm{KC1}$ $\left(\mathrm{CD} \mathrm{C}^{+} \mathrm{FCER}^{+} \mathrm{A}^{+}\right)$and $\mathrm{KC} 2\left(\mathrm{MARCO}^{+} \mathrm{LILRB}^{+} \mathrm{TIMD}^{+}\right)$ and a liver resident inflammatory macrophage subset $\left(\mathrm{LYZ}^{+}\right.$ $\mathrm{CD}^{+}{ }^{+}$). The 3 classical dendritic cell (DC) subsets were also identified, namely conventional DCs, cDC1 $\left(\mathrm{CD} 1 \mathrm{C}^{+}\right.$ $\mathrm{CLEC}^{+}$) and $\mathrm{cDC} 2\left(\mathrm{FCER}^{+} \mathrm{A}^{+} \mathrm{CD}^{+} \mathrm{E}^{+}\right.$), and plasmacytoid DCs (LILRA4 ${ }^{+} \mathrm{CLEC}^{+} \mathrm{C}^{+} \mathrm{GZMB}^{+}$) (Figure 3).

In the cirrhotic liver, scRNAseq uncovered all major immune cell populations and revealed a decrease in $\mathrm{CD}^{+}$ $\mathrm{T}$ cells, associated with an increase in $\mathrm{CD}^{+} \mathrm{T}$ cells, as compared to the healthy liver. Re-clustering of MNPs identified four subgroups, annotated as $\mathrm{KC} 1\left(\mathrm{CD} 163^{+} \mathrm{MARCO}^{+}\right.$ $\left.\mathrm{TIMD}^{\mathrm{hi}}\right), \mathrm{KC} 2\left(\mathrm{CD}_{163^{+}} \mathrm{MARCO}^{+} \mathrm{TIMD}^{\mathrm{low}}\right)$, scar-associated macrophages $\left(\mathrm{TREM}^{+} \mathrm{CD}^{+}\right)$, tissue monocytes $\left(\mathrm{MNDA}^{+}\right.$ S100A12 ${ }^{+} \mathrm{FCN1}^{+}$) (Figure 3). The $\mathrm{MARCO}^{+}$population decreases in cirrhosis compared to the healthy liver while TREM2 $^{+}$CD9 $^{+}$scar-associated macrophages, derived from circulating monocytes, expand early in the course of the disease. This latter population of cells is conserved in humans and mice and displays pro-fibrogenic properties (26). Deep clustering of mesenchymal cell populations uncovered a cluster of $\mathrm{PDGF}^{+}$cells that also expand in cirrhosis, expressing high levels of fibrillar collagens and pro-fibrogenic genes. RNA velocity experiments indicated a trajectory from human HSCs to these scar-associated mesenchymal cells, and ligand/cognate receptors analysis combined with functional studies, pointed to TNFRSF12A, PDGFRA, and Notch signaling as important regulators of mesenchymal cell function in the human liver fibrotic niche (26).

Collectively, these single cell analyses revealed contextdependent cellular phenotypic diversity, opening the field to exploring potential mechanisms involved in HCC progression from cirrhosis. For instance, the fibrotic context is associated with the emergence of scar-associated mesenchymal cells and scarassociated macrophages with pro-fibrogenic properties. Future functional studies are needed to determine the value of targeting these cell subsets or specific molecular effectors therein as therapeutic strategies in HCC.

\section{HCC SUBTYPES ACCORDING TO MOLECULAR AND IMMUNE CLASSIFICATIONS}

\section{Molecular Classification of HCC}

Progression from cirrhosis to HCC is mediated by a stepwise accumulation of somatic mutations and copy number 


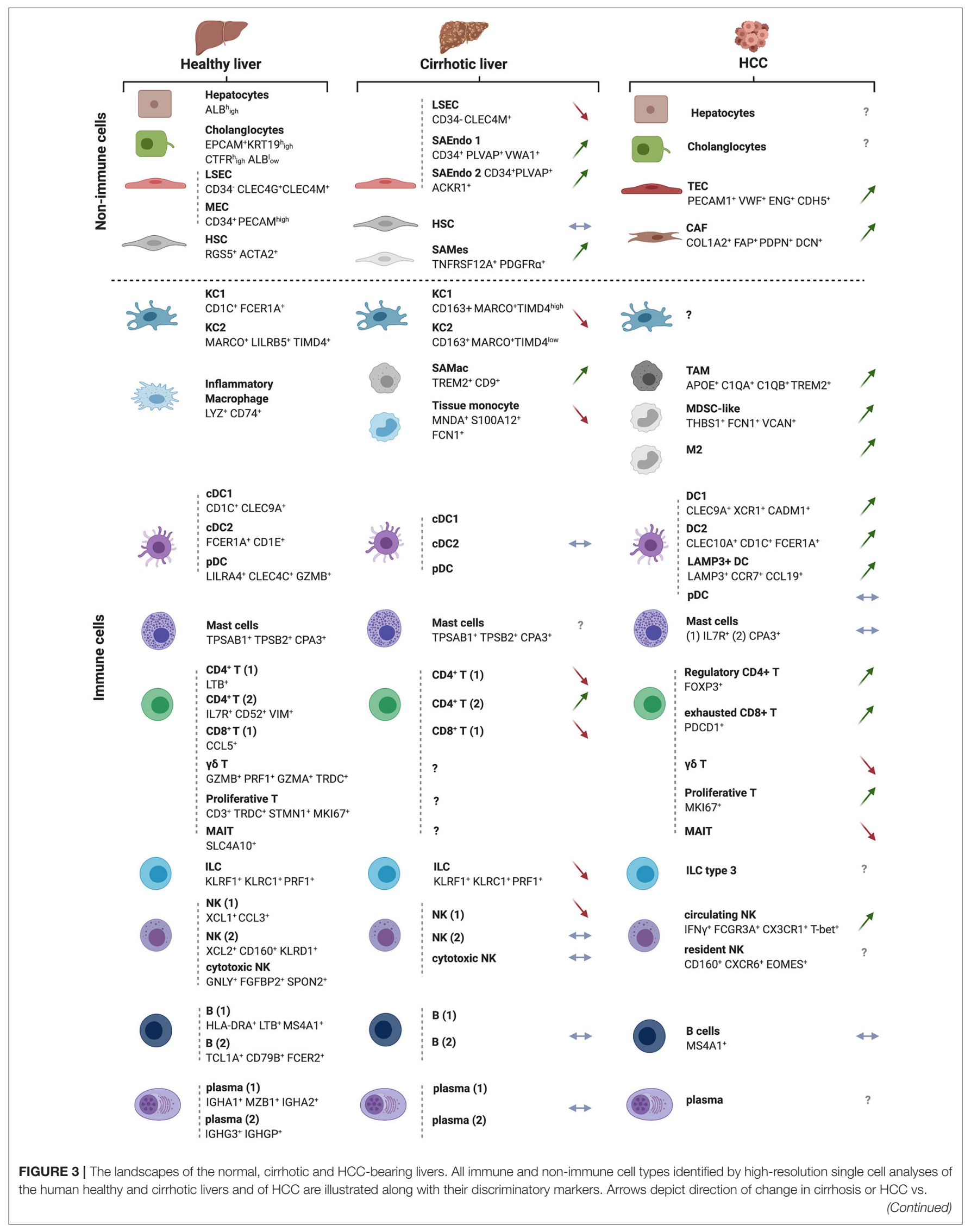


FIGURE 3 | the normal liver, with green arrows indicating an expansion, red arrows a depletion and blue horizontal arrow no change in the examined cell subset. The cellular landscapes of the healthy and cirrhotic livers were from (26). The information on the HCC landscape was from (27), but with complementary information from the following studies: $\gamma \delta$ T cells and M2 macrophages (28), cancer-associated fibroblasts (CAFs) and tumor-endothelial cells (TECs) (29). New subsets of cells arising in the cirrhotic condition are also depicted and labeled as 'scar-associated' cells: SAEndo: scar-associated endothelial cells; SAMes: scar-associated mesenchymal cells; SAMac: scar-associated macrophages, as in (26). The HCC analyses were on sorted CD45+ immune cells. Symbols for genes and associated proteins are defined in Supplementary Table 1.

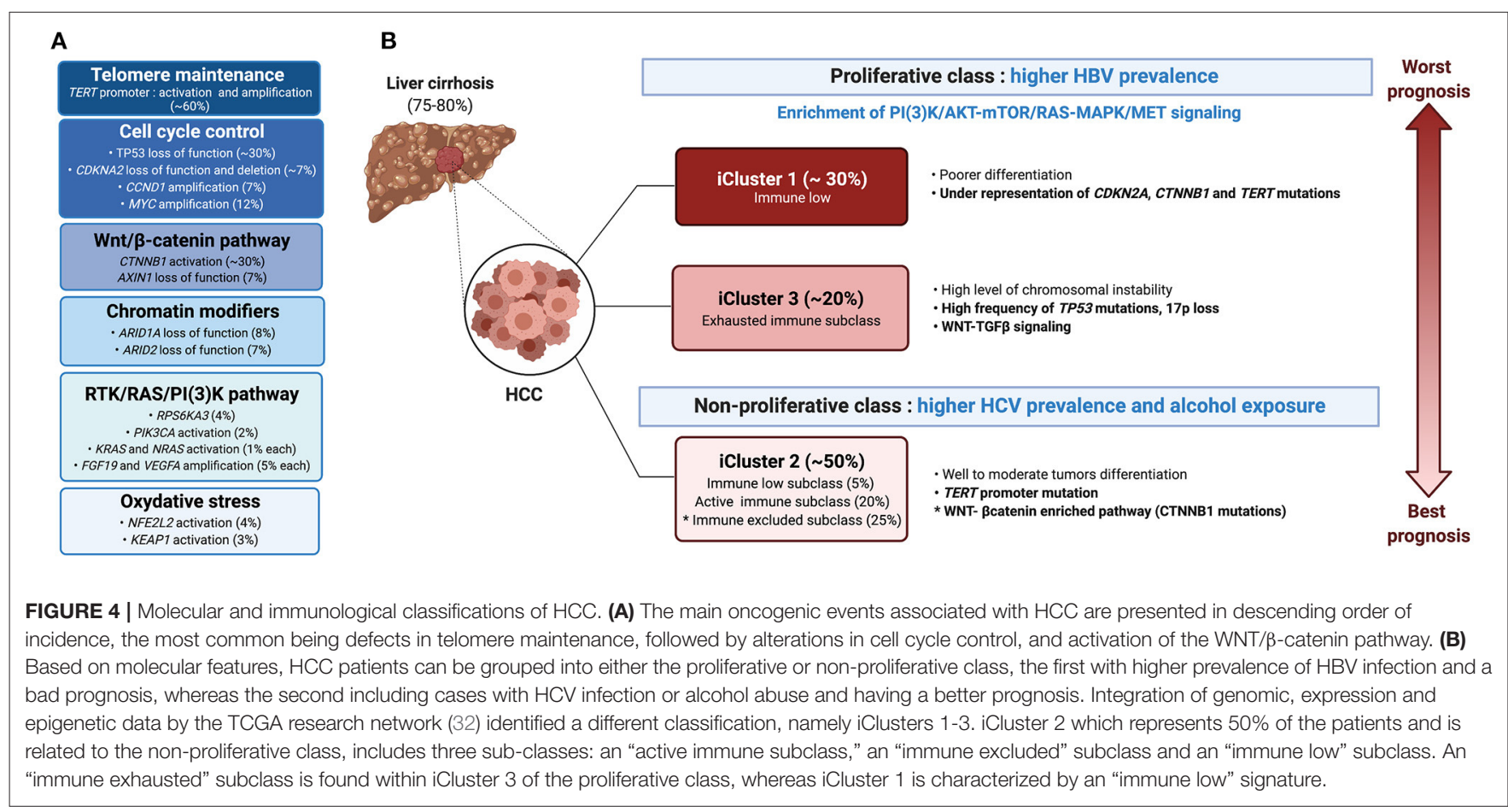

variations in driver genes (30). The most frequent alteration is the reactivation of the telomerase reverse transcriptase (TERT), a key event observed in $20 \%$ of high-grade dysplastic lesions and up to $60 \%$ of early HCC (31). Besides TERT promoter mutations that impact telomere maintenance, 10 pathways were found to be recurrently altered in HCC, including pathways involved in cell cycle control (TP53, CDKNA2, CCND1), oxidative stress (NFE2L2, KEAP1), and chromatin modification (ARID1A, ARID2), but also the Wnt/ $\beta$-catenin pathway (CTNNB1, AXIN1) and the RTK/RAS/PI3K pathway (RPS6KA3, PIK3CA, KRAS, NRAS, FGF19, VEGFA) (32) (Figure 4). The TGF $\beta$ pathway is additionally involved in HCC progression, with some tumors presenting aberrant activation of this pathway, whereas others harboring inactivating mutations in genes required for TGF $\beta$ signal transduction e.g., the SPTBN1 gene (33). Last, $\sim 20 \%$ of HCC express markers of progenitor cells, e.g., epithelial cell adhesion molecule (EpCAM) and cytokeratin 19 (CK19) and arise from either progenitors or dedifferentiated hepatocytes (12).

Earlier studies classified HCC into two main transcriptomebased classes, based on genetic, epigenetic and phenotypic features: HCC of the proliferative class, which displayed a poor clinical outcome, and HCC of the non-proliferative class, with a better outcome. The proliferative class was associated with the HBV etiology, and characterized by the activation of PI3K-AKT-mTOR, RAS-MAPK, and MET signaling along with chromosomal instability (34). The non-proliferative class, which is more prevalent in alcohol- or HCV-related HCC, regrouped heterogeneous tumors, including a subclass characterized by mutations in CTNNB1, the gene encoding $\beta$-catenin. More recent classification by Schulze et al. (35) and the Cancer Genome Atlas (TCGA) network (32) revised the molecular landscape of HCC (Figure 4). Three integrative clusters were identified: whereas, iCluster 1 and iCluster 3 distinguished two subclasses of the proliferative class, iCluster 2 overlapped with the non-proliferative class. iCluster 1 is associated with poorer differentiation, higher tumor grade, the presence of macrovascular invasion and overexpression of proliferation (PLK1, MKI67) and progenitor cells (EPCAM and AFP) gene markers, while iCluster 3 is characterized by high frequency of TP53 mutation, 17p loss and activation of WNT-TGF $\beta$ signaling. On the other end, iCluster 2 regroups heterogenous moderately differentiated tumors characterized by TERT promotor mutations. Identification of the mutational landscape of HCC unveiled several druggable targets in $>25 \%$ 
of the cases (35). However, a potential limitation of tumor cellbased therapy is a notable inter- and intra-tumoral heterogeneity, mediated in part by non-neutral selection of mutations conferring a selective advantage (30) and subclone evolution (36). Using scRNAseq of liver cancers, Ma et al. (29) identified links between intra-tumoral heterogeneity (ITH), tumor microenvironment (TME) and survival outcome. They discriminated ITH according to the average expression of 10 cancer stemness genes, namely EPCAM, CD24, CD44, CD47, KRT19, PROM1, ALDH1A1, ANPEP, ICAM1 and SOX9. This allowed them to derive diversity scores based on transcriptomic profiles, grouping the tumors into Div-high and Div-low groups. The Div-high group displayed poorer mOS and PFS, expressed higher levels of hypoxia-inducible factor 1-alpha (HIF1 $\alpha$ )-dependent VEGFA and displayed a marked TME reprogramming. Concordantly, NOTCH and VEGF signaling, together with fetal-associated endothelial cells $\left(\mathrm{PLVAP}^{+}\right.$VEGFR2 $^{+}$) found in tumors, have been demonstrated to reprogram the $\mathrm{CD}_{1} 4^{+}$monocytes into fetal-like immunosuppressive tumor-associated macrophages (TAMs (FOLR2 ${ }^{\text {high }}$ CD163 ${ }^{\text {high }}$ ) (37).

\section{Immunological Classification of HCC}

Immunological classification of HCC has been proposed by different groups using gene expression profiling (38) and protein level approaches based on multiplex immunohistochemistry (IHC) analysis (38) and mass cytometry (CyTOF) (28). Using deconvolution of 8 datasets, Llovet and colleagues analyzed a total of $956 \mathrm{HCC}$ samples and reported that $\sim 25 \%$ of HCC cases expressed an immune gene signature (39). Such an "immune class" was found to be associated with better mOS, and expressed PD-1 and PD-L1, tertiary lymphoid structures (TLS) markers and determinants of cytolytic T cells activity e.g., an IFN $\gamma$ signature. Further stratification identified two TMEbased sub-classes within the immune class, dubbed the "active immune" and the "exhausted immune" subclasses. The "active immune" sub-class was enriched in $\mathrm{T}$ cell response effectors (IFN $\gamma$ and granzyme B signatures), whereas the "exhausted immune" sub-class included signatures of $\mathrm{T}$ cell exhaustion, immunosuppressive macrophages and TGF $\beta$ signaling. A third immunological class, referred to as "immune excluded" was distinguished in $\sim 25 \%$ of HCC patients, based on the expression of immune genes, particularly an immunosuppressive signature, in the tissue surrounding the tumor, but with little immune gene expression in the tumor core. Such an "immune excluded" class was associated with a bad prognosis and overlapped with a subset of tumors in TCGA iCluster 2 with an activated WNT- $\beta$-catenin pathway (39) (Figure 4B). The immunological environment of HCC and its association with the molecular classification was further analyzed by Kurebayashi et al. (38) using multiplex immunohistochemistry. The authors classified HCC into three immune-subtypes based on the numbers of infiltrating immune cells: "Immune-high," "immune-mid" and "immune-low." Consistent with Sia et al. (39), the "immunehigh" subtype, which was enriched in T cells and B-/plasma cells, was associated with a good prognosis (38). Zhang et al. (28) expanded this analysis and defined three HCC groups, namely the "immunocompetent," "immunosuppressive," and "immunodeficient" subtypes. The immunocompetent subtype, characterized as $\mathrm{CD} 45^{\text {high }}$ FOXP $3^{\text {low }}$, had normal $\mathrm{T}$ cell infiltration including high infiltration of $\gamma \delta \mathrm{T}$ cells. On the contrary, the immunosuppressive subtype, marked by a CD45 high $F O X P 3^{\text {high }}$ staining, exhibited high frequencies of immunosuppressive cells (regulatory $\mathrm{T}$ and $\mathrm{B}$ cells and immunosuppressive macrophages) and molecules (PD-1, PDL1, TIM-3, CTLA-4, VEGF, TGF $\beta$, and IL-10). Finally, the CD $45^{\text {low }}$ immunodeficient subtype showed a reduced infiltration of lymphocytes (28). While these studies demonstrated marked heterogeneity in HCC tumors and their associated TME with broad classification of patients, in depth characterization of the immune landscape of HCC at high resolution is expected to refine patients stratification and identify putative immunetherapeutic targets.

\section{The Immune Landscape of HCC}

The immune landscape of HCC has been more recently explored using single cell approaches. In general, a progressive depletion of intrahepatic LrNK cells, cytolytic T cells and $\gamma \delta \mathrm{T}$ cells and an enrichment of regulatory $\mathrm{T}$ cells $\left(\mathrm{T}_{\text {reg }}\right)$ and macrophages occur in $\operatorname{HCC}(28,28,32,40-42)$ (Figures 3, 5). While tumorinfiltrating $\mathrm{CD}^{+} \mathrm{T}$ cells are significantly correlated with better prognosis $(38,43), \mathrm{T}_{\text {reg }}$ are associated with a poorer mOS (44). RNA velocity analysis indicated a directional flow from proliferative to exhausted $\mathrm{CD}^{+} \mathrm{T}$ cells in HCC (27). Exhaustion is characterized by the expression of a range of inhibitory receptors, including PD-1, TIM-3, LAG3, TIGIT, and LAYN [reviewed in (45)], and with reduced effector functions via TOX-mediated epigenetic and transcriptional alterations (46-48). However, not all exhausted $\mathrm{CD}^{+} \mathrm{T}$ cells are the same, as two subsets can be discriminated: $\mathrm{PD}-1^{+} \mathrm{TCF} 1^{+}$"precursors" that self-renew and give rise to $\mathrm{PD}-1^{+} \mathrm{TCF} 1^{-}$"terminally differentiated" exhausted T cells (49-51). Notably, the presence of the precursors, but not the terminally differentiated exhausted $\mathrm{T}$ cells, is associated with a better response to anti-PD-1. Similarly, NK cells display an exhausted phenotype, expressing high levels of immune checkpoints such as PD-L1, PD-1, LAG3, TIM-3, CD155, and CD96 (52, 53). Further, they produce immunosuppressive cytokines such as TGF $\beta$ and IL-10 and less IFN- $\gamma$ (52-56). The role of B lymphocytes in the development of HCC and their prognostic value is still debated. Their ADCC and antigen-presentation functions are countered by their ability to induce immunosuppression. In surgically resected HCC, $\mathrm{CD}_{20}{ }^{+} \mathrm{B}$ cells are associated with a better prognosis $(38,57)$, especially when they are in close proximity of tumor-infiltrating $\mathrm{T}$ cells (58). However, their prognostic value in the context of TLS depends on whether these are found intra-tumorally or in the surrounding tissue [reviewed in (59)]. Notably, TLS presence in the adjacent non-tumoral liver tissue was associated with an increased risk for late recurrence and a poor mOS in 82 patients with surgically resected HCC (60). Mechanistically, such ectopic TLS harbored progenitors/cancer stem cells (expressing CD44v6) and a tumor-promoting environment characterized by a persistent NF- $\kappa \mathrm{B}$ activation favoring tumor outgrowth, as demonstrated in a mouse model (60). Concordantly, alymphoid conditions suppressed $\mathrm{CD} 44 \mathrm{v} 6^{+}$HCC-initiating cells and 


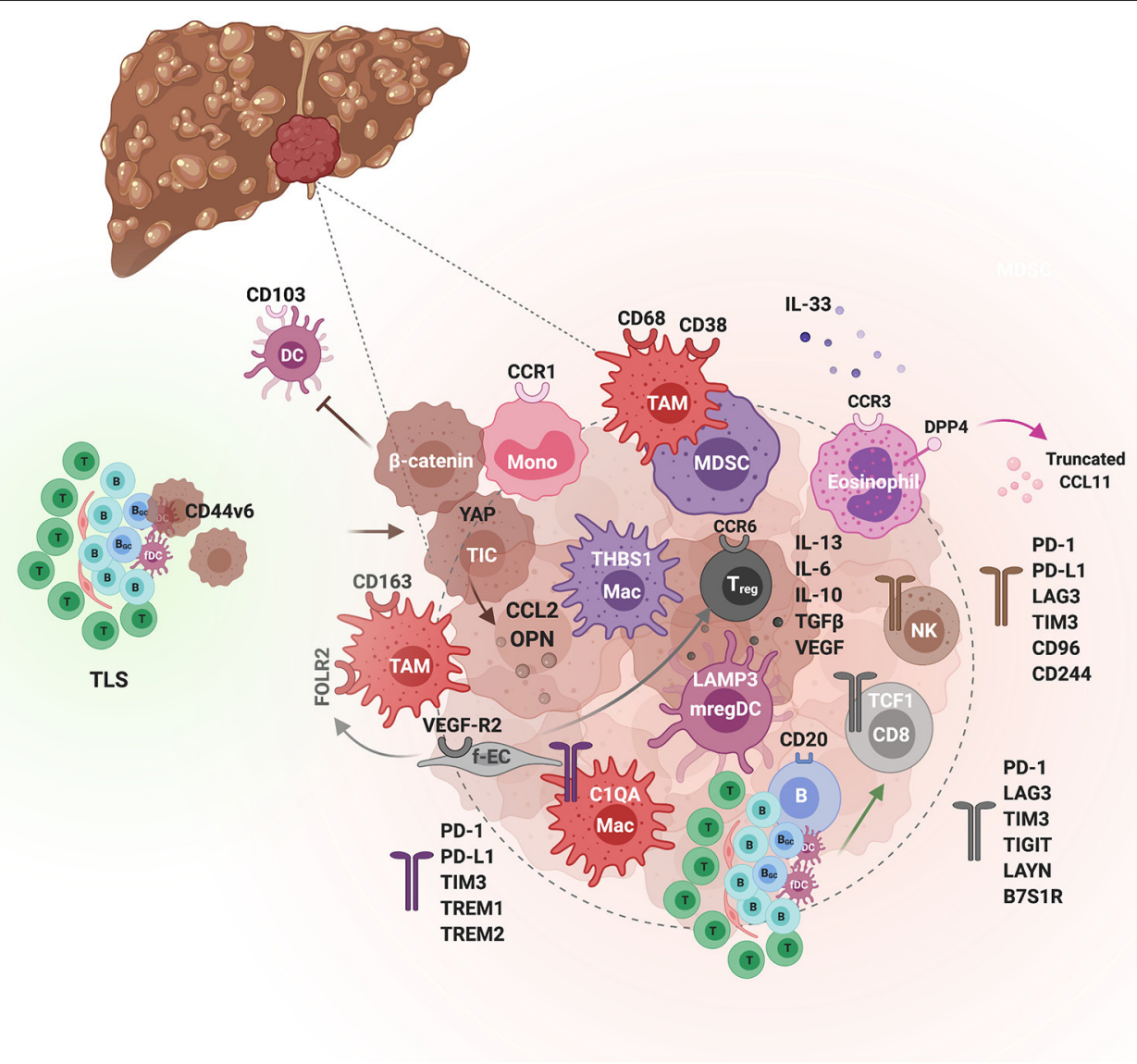

FIGURE 5 | The tumor immunological microenvironment of HCC. Schematic illustration of the different actors demonstrated to contribute to immunosuppression or immune activity in the TME of HCC. Tumor-initiating cells (TIC) and tumor cells (hues of brown) orchestrate the immunological environment by secreting inflammatory cytokines e.g., osteopontin (OPN) and chemokines e.g., the monocyte chemoattractant CCL2, which promote tumorigenesis through the recruitment of monocytes and their differentiation to tumor-associated macrophages (TAMs). In addition, $\beta$-catenin-activated tumor cells can inhibit anti-tumor immunity by blocking $\mathrm{CD} 103^{+}$ DCs tumor infiltration. Spatially, TAMs are enriched in the peri-tumoral area, express CD68, CD163, CD38, and the folate receptor (FOLR2), induced by fetal-associated endothelial cells (fEC). Two subsets of tumor-enriched macrophages can be distinguished by single cell analyses, $\mathrm{THBS}^{+}{ }^{+}$macrophages and $\mathrm{C1QA}{ }^{+}$ macrophages, with an MDSC and TAM signature, respectively. The latter is associated with a poor prognosis in HCC. The immunosuppressive activity of TAMs is mediated by various immune checkpoints, including PD-1, PD-L1, TIM-3, TREM1 and TREM2. Besides TAMs, the TME is enriched in Treg but depleted of other T cells and NK cells, which when present exhibit an exhausted phenotype. Among the CD8 T cells, The PD-1+ TCF1+ "precursors" are associated with a good response to anti-PD-1. TLS found in the adjacent non-tumoral liver tissue are associated with a poor prognosis as they can harbor progenitor/cancer stem cells (expressing CD44v6) and promote tumorigenesis by impairing the clearance of senescent hepatocytes. In contrast, intratumoral TLS and CD20+ $\mathrm{B}$ cells are predictive of a lower risk of relapse and a better CD8 T cell anti-tumor activity. Eosinophils also confer a tumorilytic activity, and enhancing their recruitment with inhibitors of the CCL11 peptidase DPP4 improved the efficacy of anti-PD-1+anti-CTLA4 immunotherapy.

prevented hepatocarcinogenesis $(60,61)$. Additionally, B cells favored HCC progression by limiting the resolution of senescence-mediated liver fibrosis (62). In contrast, it was recently shown that intra-tumoral TLS were predictive of a lower risk of early relapse after surgical resections, as analyzed in 273 patients (63). In contrast, $\mathrm{CD}^{+} 8^{+} \mathrm{CD} 163^{+}$TAMs, which accumulate at the tumor margin, and $\mathrm{CCR} 1^{+}$monocytes, are associated with bad mOS (64-66). TAMs are recruited to HCC in response to CCL2. The expression of the CCL2 gene is controlled by diverse mechanisms including through APOBEC3B-mediated de-repression of epigenetic marks in its promoter (67), and through Yes-associated protein (YAP) transcriptional regulation, as shown in tumor-initiating cells (TICs) (68). Together with IL-13, CCL2 drives the metastasis of MYC/Twist1 tumors (69). TAMs contribute to HCC malignant progression and metastasis through diverse mechanisms, e.g., via the production of cytokines such as IL-6 (70) and hepatocyte compensatory proliferation (71), immunosuppression and induction of epithelial-to-mesenchymal transition (EMT) [reviewed in (72)]. The immune checkpoint TIM-3, induced by TGF $\beta$ in the tumor microenvironment (TME), is implicated in the pro-tumoral effects of TAMs in HCC (70). Similarly, the receptors Triggering Receptor Expressed on Myeloid cells (TREM)1 (73) and TREM2 (74) have been demonstrated to promote the dysfunction and 
apoptosis of cytotoxic $\mathrm{CD}^{+} \mathrm{T}$ cells in HCC, while enhancing the recruitment of $\mathrm{CCR}^{+}{ }^{+}$Foxp $^{+}{ }^{+}$Tregs. Platelets, key effectors of immune-mediated tissue damage, have also been implicated in HCC. Using different mouse models of dietary-inducing NASH and data from human patients, Malehmir et al. (75) demonstrated enhanced platelets influx, aggregation and activation in liver sinusoids in NASH. This was mediated by their interaction with $\mathrm{KCs}$, involving hyaluronic acid/CD44 binding and the platelet receptor glycoprotein $1 \mathrm{~b}$ alpha (GPIb $\alpha$ ). Anti-platelet treatments, including aspirin, or specific blockade of GPIb $\alpha$ blunted the development of NASH, through limiting CD8 T lymphocytes, NKT cells and KC recruitment. In the HBsAg transgenic mouse model of HCC, platelets were similarly shown to promote the recruitment of HBsAg-specific CD8 T cells that elicit cycles of hepatocyte killing and inflammation leading to fibrosis. Inhibition of platelet activation potently reduced the development of HCC in this model (76).

scRNAseq of sorted $\mathrm{CD} 45^{+}$cells from the tumor, adjacent liver, hepatic lymph nodes, blood, and ascites of 16 treatmentnaive HCC patients recovered all of the major cell populations such as T, B, NK and myeloid cells, but also few minor cell populations including mast cells and ILCs (27) (Figure 3). All types of $\mathrm{T}$ cells (including Treg, exhausted $\mathrm{T}$ cells [Tex] and proliferative $\mathrm{T}$ cells) were enriched in the tumors, as previously reported (77). Four clusters of NK cells, enriched in the tumor, were identified, including two circulating $\mathrm{NK}$ clusters $\left(\mathrm{IFN} \gamma^{+} \mathrm{FCGR}^{+} \mathrm{A}^{+} \mathrm{CX} 3 \mathrm{CR} 1^{+}{ }^{+}\right.$T-bet $\left.^{+}\right)$and two LrNK clusters $\left(\mathrm{CD}_{160^{+}} \mathrm{CXCR6}^{+}\right.$EOMES $\left.^{+}\right)$. However, their respective roles in tumorigenesis and patients prognosis have not been addressed. A diverse repertoire of functionally distinct myeloid cells were identified, particularly, two subsets of macrophages within the tumors: THBS1+ macrophages enriched in myeloidderived suppressor cell (MDSC) genes (S100A genes, FCN1 and VCAN) and C1QA+ macrophages, enriched in tumor associated macrophage (TAM) genes APOE, C1QB and TREM2 (Figures 3, 5). Only the latter was associated with a poor prognosis in the TCGA liver hepatocellular carcinoma (LIHC) cohort. In parallel, 3 intra-tumoral clusters of DCs were distinguished, namely $\mathrm{cDC} 2$ (highly expressing CD1C, FCER1A, and CLEC10A), cDC1 (highly expressing CLEC9A, XCR1 and CADM1) and a non-classical LAMP ${ }^{+}$DCs (highly expressing CCR7, LAMP3, CD80 and CCL19) with migration capacity toward the lymph nodes. Interestingly, ligand-receptor pairs analysis indicated that the $\mathrm{LAMP}^{+}$DCs are the subset that would interact with Tex cells and $\mathrm{T}_{\text {regs. }}$. This LAMP3 population seems to correspond to mregDCs, a DC cluster annotated in human lung cancer as a population involved in tumor antigen uptake and expressing immunoregulatory molecules $(78,79)$.

\section{HCC Patients Response to ICls}

PD-1 is primarily expressed on the surface of activated T cells, but also on NK/NKT cells (54), B cells (80) and myeloid cells including monocytes, DCs, MDSCs and TAMs (81). Its induction in response to cytokine signaling is tightly regulated at the epigenetic and post-transcriptional levels $(48,81,82)$. Recently, two studies used multiparametric flow cytometry and multiplex IHC to show that higher intratumoral frequency of $\mathrm{PD}-1^{\text {high }} \mathrm{CD} 8^{+} \mathrm{T}$ cells $(83)$ and $\mathrm{CD} 38^{+} \mathrm{CD}^{+} 8^{+}$macrophages (84) was strongly associated with improved response to ICI in patients with advanced HCC. PD-L1 is expressed by DCs, monocytes, macrophages, B cells, NK cells, LSECs, and tumor cells. Its expression is induced by hypoxia (73), among other mechanisms. PD-L1 expression on tumor-infiltrating immune cells is associated with a better prognosis while the prognostic value of its expression on neoplastic cells is controversial $(39,43)$. Further, the response of patients with HCC to Nivolumab (antiPD1) was not found to be associated with PD-L1 expression on tumor cells, implicating other PD-L1 expressing cells in this response (15). In murine models with transplantable HCC, PD-L1 expression on myeloid cells mediated the anti-PD-L1 response (85).

Previous studies in melanoma and non-small cell lung cancer (NSCLC) have attributed the response to ICIs to tumor mutational burden $(86,87)$, levels of neo-antigens $(88)$ or tumorspecific antigens $(89,90)$, the presence of TLS [reviewed in (59)] or specific oncogenic pathways $(91,92)$. Nonetheless, the mechanisms involved in patients response to ICIs, particularly in HCC, remain for the most part unclear. For example, the mutational burden did not correlate with ICI response in HCC (93), and neither the mutational load nor the presence of neoantigens was associated with the immune class, which predicted a favorable response to ICI therapy (39). Instead, the activation of $\beta$-catenin was associated with resistance to ICI, as demonstrated in a mouse model (94) (Figure 4). Using a MYC; $p 53^{-/-}$HCC mouse model, Ruiz de Galarreta et al. (94) demonstrated that $\beta$-catenin promoted immune escape by preventing the recruitment of $\mathrm{CD}_{103}{ }^{+} \mathrm{DCs}$, impairing antigenspecific $\mathrm{T}$ cells-mediated anti-tumor immunity. Accordingly, activating mutations in CTNNB1 correlate with resistance to ICI monotherapy with either anti-PD-1 or anti-PD-L1, as shown in a prospective sequencing analysis of 27 evaluable advanced HCC patients, in which none of the 10 patients with WNT pathway alterations achieved clinical benefit, whereas around half of the non-WNT pathway-altered patients showed durable stable disease (93). Nevertheless, these results also show that $50 \%$ of ICI non-responders harbor mechanisms unrelated to $\beta$-catenin activation. Treating fibrosis using a TGF $\beta$ neutralizing antibody in the STAM ${ }^{\mathrm{TM}}$ mouse model fibrosis-associated HCC, triggered a redistribution of $\mathrm{CD}^{+}$ lymphocytes into the tumors, which re-invigorated anti-tumor response (95). These results are consistent with those of Mariathasan et al. (96), who reported that TGF $\beta$ attenuated the response to PD-L1 blockade by restricting intra-tumoral Tcell infiltration. Since TGF $\beta$ alterations are found in a subset of HCC patients (33), agents that block this pathway should be tested in this group, highlighting the need for personalized medicine. Similarly, the immunosuppressive molecule VEGF was found to be enriched in a subset of HCC patients, particularly those with Div-high tumors, supporting the use of the anti-PD-L1 (Atezolizumab) + anti-VEGF (Bevacizumab) combination. However, the cellular subsets, putative signaling pathways, and associated biomarkers required for an effective patient's response to this new combination therapy require 
further exploration. The etiology of HCC might contribute to the heterogeneity in patients' response to immunotherapy. Indeed, Lim et al. (44) reported that the TME of HBV-related HCC is more immunosuppressive than that of non-viral HCC. Particularly, $\mathrm{PD}-1^{\text {high }}$ Tregs and $\mathrm{PD}-1^{+} \mathrm{CD} 8^{+}$resident memory $\mathrm{T}$ cells were more prominent in $\mathrm{HBV}$-related HCC, suggesting that PD-1 blockade might be a suited strategy for this etiology. In contrast, immunotherapies that target CD244 ${ }^{+} \mathrm{NK}$ cells and Tim $-3^{+} \mathrm{CD}^{+} \mathrm{T}$ cells, enriched in non-viral HCC, may be more effective in those patients (44).

\section{ICI Combination Therapies}

Several pre-clinical studies and ongoing clinical trials (Table 1) are exploring the potential of combining different ICIs. For e.g., a phase III trial is currently testing the combination of durvalumab (anti-PD-L1) and tremelimumab (anti-CTLA4) as a first line therapy (NCT03298451). The combinations of ICIs together with ablation (97), chemo-radioembolization or targeted therapies (TKi or anti-VEGF) in the adjuvant or neoadjuvant setting are also being explored (Table 1). For e.g., two trials are testing the combination of pembrolizumab + Lenvatinib (NCT 03006926) or of pembrolizumab + regorafenib (NCT03347292) for first line therapies. Radioembolization was reported to elicit an immune response, both locally and systemically, leading to enhanced infiltration of TIM- $3^{+}$tumorinfiltrating lymphocytes (TILs), NK, and NKT cells (98). It is thus plausible that an ICI targeting TIM-3 might enhance the clinical response of radioembolization or other interventions in HCC patients. A phase II trial is currently testing cobolimab, a TIM-3 binding antibody, in combination with anti-PD-1 on the response of patients with locally advanced or metastatic liver cancer (NCT03680508). Similarly, combining multiple strategies targeting inhibitory receptors (PD-1, TIM-3, LAG3, CTLA4, TREM1, TREM2) and/or their ligands (PD-L1, B7 superfamily member1 [B7S1]) have shown synergistic effects in restoring TILs anti-tumoral immune responses in pre-clinical studies (73, $74,99-102)$ and enhancing NK cell infiltration and activity (52-56, 103). Additional strategies include the inhibition of TAM recruitment, their polarization to an immunosuppressive phenotype or their function in hampering anti-tumor immunity or promoting tumorigenesis. The pro-inflammatory protein osteopontin (OPN) produced by cancer cells has been implicated in cancer promotion and metastasis, through the stimulation of CSF1 signaling in TAMs. Blockade of the CSF1/CSF1R pathway enhanced the efficacy of anti PD-L1 in OPN-overexpressing HCC, by reducing macrophage recruitment (102). Blockade of the CCL2/CCR2 axis was also shown to inhibit the recruitment of TAMs leading to enhanced infiltration of $\mathrm{CD}^{+} \mathrm{T}$ cells and improved anti-tumor immunity (104). However, this approach should be considered with caution as some macrophages exert anti-tumoral activity. Indeed, Eggert et al. (105) reported that the CCL2-CCR2 axis promotes the clearance of senescent hepatocytes preventing HCC outgrowth in mice. Among the TAM targets that recently surfaced as critical inhibitors of antitumor immunity are the receptors TREM1 and TREM2. Blockade of TREM1 (73) or TREM2 (74) attenuated immunosuppression and $\mathrm{CD}^{+} \mathrm{T}$ cell dysfunction boosting the efficacy of antiPD-1/PD-L1 immunotherapy. An alternative approach to skew TAM functions is through vaccination. Using a mouse model, a recent study demonstrated that a Listeria-based HCC vaccine enhanced the efficacy of PD-1 blockade by skewing the TAMs to an anti-tumoral phenotype (106). Consistent with the improved patients response to the anti-PD-L1 + anti-VEGF combination therapy, it has been recently demonstrated using murine models of HCC that this approach fortified hepatic vessels and overcame resistance to either monotherapy (107). Last, a less studied immune cell population in the context of anti-tumor immunity are the eosinophils, which were recently shown in a murine model of HCC to promote tumor-cell killing through degranulation and contribute to the efficacy of the anti-PD1 + anti-CTLA4 combination immunotherapy. Their recruitment in response to the cancer-cell secreted alarmin IL-33, is mediated by the chemokine CCL11, and enhanced with the administration of sitagliptin, an inhibitor of dipeptidyl peptidase DPP4 (CD26) that cleaves CCL11. These results suggest that combined modulation of both type 1 and 2 immune responses may improve therapeutic management of HCC (108).

\section{THE FUTURE OF IMMUNOTHERAPIES IN HCC BEYOND ICI}

Besides ICI, several immunotherapeutic strategies for HCC patients are emerging, such as targeted therapies promoting ADCC, adoptive cell therapy (ACT), including the transfer of autologous CD8 T cells, iNKT cells, $\gamma \delta \mathrm{T}$ cells, cytokine-induced immune killer cells (IKC), chimeric antigen receptor (CAR)-T cells, oncolytic viruses and vaccines (Figure 6). For a number of these strategies, tumor-specific antigens (TSA) or tumorassociated antigens (TAA) are targeted. In HCC, these include $\alpha$-fetoprotein (109-111), hTERT (112), glypican-3 (GPC3) (113115), p53 (116), melanoma antigen gene A (MAGE-A) (117), squamous cell carcinoma antigen recognized by $\mathrm{T}$ cells (SART) (118), and NY-ESO-1 (119). More recently, the oncogenic phosphatase PRL3 was confirmed as a TAA, as it was shown to be expressed in tumors, but not in patient-matched normal tissue, across 11 cancers. A humanized antibody targeting this TAA, PRL3-zumab, was shown to enhance the intra-tumoral recruitment of $\mathrm{B}$ cells, NK cells and macrophages, suggesting that this antibody might promote tumor killing by ADCC (120). Similarly, the elevated expression of GPC3 in $>70 \%$ of HCC, and its association with poor prognosis (121), has led to the development of several immunotherapeutic strategies, including the humanized monoclonal antibody codrituzumab (122), bispecific antibodies (123), CAR-T cells (124), antibody-drug conjugates (125), and vaccines (126). GPC3-CAR-T cells have been shown to be polyfunctional and capable of eliminating HCC in a transplantable orthotopic mouse model (127), and there are currently at least 5 phase I clinical trials recruiting patients with HCC to test GPC3-CAR-T cells (Table 1; ClinicalTrials.gov, December 2020). Another CAR-T cell tested in multiple solid tumors including HCC is the EpCAM-CAR-T, as registered 
TABLE 1 | Clinical trials of immunotherapies for HCC.

\begin{tabular}{|c|c|c|c|c|c|}
\hline Immunotherapy & Identifier & Study title & Interventions & Number enrolled & $\begin{array}{l}\text { Primary } \\
\text { completion }\end{array}$ \\
\hline \multicolumn{6}{|l|}{ Phase III clinical trials } \\
\hline \multicolumn{6}{|l|}{$I C I+$ combinations } \\
\hline \multirow[t]{5}{*}{ ICl as Adjuvant (Stage A) } & NCT03867084 & $\begin{array}{l}\text { Safety and Efficacy of Pembrolizumab (MK-3475) vs. Placebo as Adjuvant } \\
\text { Therapy in Participants With Hepatocellular Carcinoma(HCC) and Complete } \\
\text { Radiological Response After Surgical Resection or Local Ablation (MK-3475-937/ } \\
\text { KEYNOTE-937) }\end{array}$ & $\begin{array}{l}\text { Biological: Pembrolizumab } \\
\text { Drug: Placebo }\end{array}$ & 950 & June 2025 \\
\hline & NCT03383458 & $\begin{array}{l}\text { A Study of Nivolumab in Participants With Hepatocellular Carcinoma Who Are at High Risk } \\
\text { of Recurrence After Curative Hepatic Resection or Ablation (CheckMate 9DX) }\end{array}$ & $\begin{array}{l}\text { Biological: Nivolumab } \\
\text { Other: Placebo }\end{array}$ & 530 & Jan 2023 \\
\hline & NCT04102098 & $\begin{array}{l}\text { A Study of Atezolizumab Plus Bevacizumab vs. Active Surveillance as Adjuvant Therapy in } \\
\text { Patients With Hepatocellular Carcinoma at High Risk of Recurrence After Surgical Resection } \\
\text { or Ablation (IMbrave050) }\end{array}$ & $\begin{array}{l}\text { Drug: Atezolizumab } \\
\text { Drug: Bevacizumab }\end{array}$ & 662 & Mar 2023 \\
\hline & NCT03847428 & $\begin{array}{l}\text { Assess Efficacy and Safety of Durvalumab Alone or Combined With Bevacizumab in High } \\
\text { Risk of Recurrence HCC Patients After Curative Treatment (EMERALD-2) }\end{array}$ & $\begin{array}{l}\text { Drug: Durvalumab } \\
\text { Drug: Bevacizumab } \\
\text { Other: Placebo }\end{array}$ & 888 & Sept 2022 \\
\hline & NCT03859128 & $\begin{array}{l}\text { Toripalimab or Placebo as Adjuvant Therapy in Hepatocellular Carcinoma After Curative } \\
\text { Hepatic Resection (JUPITER 04) }\end{array}$ & $\begin{array}{l}\text { Biological: TORIPALIMAB } \\
\text { INJECTION (JSO01) }\end{array}$ & 402 & Oct 2022 \\
\hline \multirow[t]{6}{*}{$\begin{array}{l}(C I+T A C E \\
\text { (Stage B) }\end{array}$} & NCT04229355 & $\begin{array}{l}\text { DEB-TACE Plus Lenvatinib or Sorafenib or PD-1 Inhibitor for Unresectable } \\
\text { Hepatocellular Carcinoma }\end{array}$ & $\begin{array}{l}\text { Drug: DEB-TACE plus Sorafenib } \\
\text { Drug: DEB-TACE plus Lenvatinib } \\
\text { Drug: DEB-TACE plus } \\
\text { PD-1 inhibitor }\end{array}$ & 90 & Dec 2022 \\
\hline & NCT04246177 & $\begin{array}{l}\text { Safety and Efficacy of Lenvatinib (E7080/MK-7902) With Pembrolizumab (MK-3475) in } \\
\text { Combination With Transarterial Chemoembolization (TACE) in Participants With } \\
\text { Incurable/Non-metastatic Hepatocellular } \\
\text { Carcinoma (MK-7902-012/E7080-G000-318/LEAP-012) }\end{array}$ & & & \\
\hline & NCT03949231 & $\begin{array}{l}\text { Infusion of Toripalimab Via Hepatic Arterial vs. Vein for Immunotherapy of } \\
\text { Advanced Hepatocellular Carcinoma }\end{array}$ & Drug: Toripalimab & 200 & Jan 2022 \\
\hline & NCT03755739 & $\begin{array}{l}\text { Trans-Artery/Intra-Tumor Infusion of Checkpoint Inhibitors for Immunotherapy of Advanced } \\
\text { Solid Tumors }\end{array}$ & $\begin{array}{l}\text { Drug: Checkpoint inhibitor (CPI) } \\
\text { such as Pembrolizumab }\end{array}$ & 200 & Nov 2033 \\
\hline & NCT04268888 & Nivolumab in Combination With TACE/TAE for Patients With Intermediate Stage HCC & $\begin{array}{l}\text { Drug: Nivolumab and TACE/TAE } \\
\text { Procedure: TACE/TAE }\end{array}$ & 522 & June 2025 \\
\hline & NCT0378957 & $\begin{array}{l}\text { A Global Study to Evaluate Transarterial Chemoembolization (TACE) in Combination With } \\
\text { Durvalumab and Bevacizumab Therapy in Patients With Locoregional Hepatocellular } \\
\text { Carcinoma (EMERALD-1) }\end{array}$ & $\begin{array}{l}\text { Drug: Durvalumab } \\
\text { Drug: Bevacizumab } \\
\text { Other: Placebo } \\
\text { Procedure: Transarterial } \\
\text { Chemoembolization (TACE) }\end{array}$ & 600 & Aug 2021 \\
\hline $\begin{array}{l}\text { ICI }+ \text { stereotaxic } \\
\text { radiotherapy } \\
\text { (Stage B) }\end{array}$ & NCT04167293 & $\begin{array}{l}\text { Combination of Sintilimab and Stereotactic Body Radiotherapy in Hepatocellular } \\
\text { Carcinoma (ISBRT01) }\end{array}$ & $\begin{array}{l}\text { Radiation: stereotactic body } \\
\text { radiotherapy } \\
\text { Drug: Sintilimab }\end{array}$ & 116 & Nov 2021 \\
\hline $\begin{array}{l}\text { Monotherapy } \\
\text { (Stage C) }\end{array}$ & NCT02576509 & $\begin{array}{l}\text { An Investigational Immuno-therapy Study of Nivolumab Compared to Sorafenib as a First } \\
\text { Treatment in Patients With Advanced Hepatocellular Carcinoma }\end{array}$ & $\begin{array}{l}\text { Drug: Nivolumab } \\
\text { Drug: Sorafenib }\end{array}$ & 743 & May 2019 \\
\hline
\end{tabular}


TABLE 1 | Continued

\begin{tabular}{|c|c|c|c|c|c|}
\hline Immunotherapy & Identifier & Study title & Interventions & Number enrolled & $\begin{array}{l}\text { Primary } \\
\text { completion }\end{array}$ \\
\hline & NCT03412773 & Phase 3 Study of Tislelizumab vs. Sorafenib in Participants With Unresectable HCC & $\begin{array}{l}\text { Drug: Tislelizumab } \\
\text { Drug: Sorafenib }\end{array}$ & 674 & June 2021 \\
\hline \multirow[t]{2}{*}{$I C l+\alpha V E G F($ Stage $C)$} & NCT03434379 & $\begin{array}{l}\text { A Study of Atezolizumab in Combination With Bevacizumab Compared With Sorafenib in } \\
\text { Patients With Untreated Locally Advanced or Metastatic Hepatocellular Carcinoma } \\
\text { [IMbrave150] (IMbrave150) }\end{array}$ & $\begin{array}{l}\text { Drug: Atezolizumab } \\
\text { Drug: Bevacizumab } \\
\text { Drug: Sorafenib }\end{array}$ & 480 & Feb 2021 \\
\hline & NCT03794440 & $\begin{array}{l}\text { A Study to Evaluate the Efficacy and Safety of Sintilimab in Combination With IBI305 } \\
\text { (Anti-VEGF Monoclonal Antibody) Compared to Sorafenib as the First-Line Treatment for } \\
\text { Advanced Hepatocellular Carcinoma. }\end{array}$ & $\begin{array}{l}\text { Drug: Sintilimab } \\
\text { Drug: IBI305 } \\
\text { Drug: Sorafenib }\end{array}$ & 566 & Dec 2022 \\
\hline \multirow[t]{3}{*}{$I C l+T K i($ Stage $C)$} & NCT03713593 & $\begin{array}{l}\text { Safety and Efficacy of Lenvatinib (E7080/MK-7902) in Combination With Pembrolizumab } \\
\text { (MK-3475) vs. Lenvatinib as First-line Therapy in Participants With Advanced Hepatocellular } \\
\text { Carcinoma (MK-7902-002/E7080-G000-311/LEAP-002) }\end{array}$ & $\begin{array}{l}\text { Drug: lenvatinib } \\
\text { Biological: pembrolizumab } \\
\text { Drug: saline placebo }\end{array}$ & 750 & May 2022 \\
\hline & NCT03764293 & $\begin{array}{l}\text { A Study to Evaluate SHR-1210 in Combination With Apatinib as First-Line Therapy in } \\
\text { Patients With Advanced HCC }\end{array}$ & $\begin{array}{l}\text { Drug: SHR-1210 } \\
\text { Drug: Apatinib } \\
\text { Drug: Sorafenib }\end{array}$ & 510 & Dec 2021 \\
\hline & NCT03755791 & $\begin{array}{l}\text { Study of Cabozantinib in Combination With Atezolizumab vs. Sorafenib in Subjects With } \\
\text { Advanced HCC Who Have Not Received Previous Systemic Anticancer } \\
\text { Therapy (COSMIC-312) }\end{array}$ & $\begin{array}{l}\text { Drug: Cabozantinib } \\
\text { Drug: Sorafenib } \\
\text { Drug: Atezolizumab }\end{array}$ & 740 & June 2021 \\
\hline \multirow[t]{2}{*}{$\mathrm{ICl}+\mathrm{ICl}($ Stage $\mathrm{C})$} & NCT03298451 & $\begin{array}{l}\text { Study of Durvalumab and Tremelimumab as First-line Treatment in Patients With Advanced } \\
\text { Hepatocellular Carcinoma (HIMALAYA) }\end{array}$ & $\begin{array}{l}\text { Drug: Durvalumab } \\
\text { Drug: Tremelimumab (Regimen } \\
\text { 1) } \\
\text { Drug: Tremelimumab (Regimen } \\
\text { 2) } \\
\text { Drug: Sorafenib } \\
\text { Drug: Durvalumab (Regimen 1) } \\
\text { Drug: Durvalumab (Regimen 2) }\end{array}$ & 1324 & Dec 2020 \\
\hline & NCT04039607 & $\begin{array}{l}\text { A Study of Nivolumab in Combination With Ipilimumab in Participants With Advanced } \\
\text { Hepatocellular Carcinoma (CheckMate 9DW) }\end{array}$ & $\begin{array}{l}\text { Drug: Nivolumab } \\
\text { Drug: Ipilimumab } \\
\text { Drug: Sorafenib } \\
\text { Drug: lenvatinib }\end{array}$ & 650 & Mar 2023 \\
\hline \multirow[t]{3}{*}{ ACT } & NCT02678013 & RFA+Highly-purified CTL vs. RFA Alone for Recurrent HCC & $\begin{array}{l}\text { Procedure: RFA } \\
\text { Procedure: } \\
\text { RFA+highly-purified CTL }\end{array}$ & 210 & Jan 2020 \\
\hline & NCT02709070 & Resection+Highly Purified CTL vs. Resection Alone for HCC & $\begin{array}{l}\text { Procedure: resection } \\
\text { Procedure: highly-purified CTL }\end{array}$ & 210 & Mar 2020 \\
\hline & NCT03592706 & Autologous Immune Killer Cells to Treat Liver Cancer Patients as an Adjunct Therapy & $\begin{array}{l}\text { Biological: IKC (Immune Killer } \\
\text { Cells) } \\
\text { Procedure: TACE (Transcatheter } \\
\text { Arterial Chemoembolization) }\end{array}$ & 60 & Feb 2021 \\
\hline ov & NCT02562755 & $\begin{array}{l}\text { Hepatocellular Carcinoma Study Comparing Vaccinia Virus Based Immunotherapy Plus } \\
\text { Sorafenib vs. Sorafenib Alone }\end{array}$ & $\begin{array}{l}\text { Biological: Pexastimogene } \\
\text { Devacirepvec (Pexa Vec) } \\
\text { Drug: Sorafenib }\end{array}$ & 600 & Dec 2020 \\
\hline
\end{tabular}


TABLE 1 | Continued

Immunotherapy

Identifier

Study title

Interventions

Number enrolled Primary

completion

Vax NCT02232490 Liver Cancer Immunotherapy: Placebo-controlled Clinical Trial of Hepcortespenlisimut-L

Biological: hepcortespenlisimut-L

\section{Phase II clinical trials}

\section{$\mathrm{ICl}+$ combinations}

Neoadjuvant (Stage A)

NCT03222076

NCT03510871

NCT03630640

NCT03682276

NCT0417478

NCT03638141

NCT04273100

NCT03817736

NCT04522544

NCT04518852

NCT03937830
Nivolumab With or Without Ipilimumab in Treating Patients With Resectable Liver Cancer

Nivolumab Plus Ipilimumab as Neoadjuvant Therapy for Hepatocellular Carcinoma (HCC) Neoadjuvant and Adjuvant Nivolumab in HCC Patients Treated by Electroporation

Safety and Bioactivity of Ip Hepatocellular Carcinoma

Neoadjuvant Therapy for Hepatocellular Carcinoma

CTLA-4 /PD-L1 Blockade Following Transarterial Chemoembolization (DEB-TACE) in Patients With Intermediate Stage of HCC (Hepatocellular Carcinoma) Using Durvalum and Tremelimumab

PD-1 Monoclonal Antibody, Lenvatinib and TACE in the Treatment of HCC

Sequential TransArterial Chemoembolization and Stereotactic RadioTherapy With ImmunoTherapy for Downstaging Hepatocellular Carcinoma for Hepatectomy

Durvalumab (MEDI4736) and Tremelimumab in Combination With Either Y-90 SIRT or TACE for Intermediate Stage HCC With Pick-the-winner Design

TACE, Sorafenib and PD-1 Monoclonal Antibody in the Treatment of HCC

Combined Treatment of Durvalumab, Bevacizumab, Tremelimumab and Transarterial Chemoembolization (TACE) in Subjects With Hepatocellular Carcinoma or Biliary Tract Carcinoma
Biological: Placebo

Biological: Ipilimumab Biological: Nivolumab

Drug: nivolumab, ipilimumab

Drug: Nivolumab Injection [Opdivo]

Biological: Ipilimumab Biological: Nivolumab

Drug: Sintilimab Injection

Drug: TACE

Drug: Durvalumab

Tremelimumab (Cohort A

dose)

Drug: Tremelimumab (Cohort

B dose)

Combination Product: PD-

mAb combined with TACE

and lenvatinib

Procedure: TACE

Radiation: SBRT

Drug: Immune

Checkpoint Inhibitor

Drug: Tremelimumab

Drug: Durvalumab

Procedure: Y-90 SIRT

Procedure: TACE

Combination Product: TACE

combined with sorafenib and

PD-1 mAb

Drug: durvalumab

Drug: Doxorubicin-Eluting Beads

Procedure: TACE

(and 2 more...) 
TABLE 1 | Continued

\begin{tabular}{|c|c|c|c|c|c|}
\hline Immunotherapy & Identifier & Study title & Interventions & Number enrolled & $\begin{array}{l}\text { Primary } \\
\text { completion }\end{array}$ \\
\hline & NCT03817736 & $\begin{array}{l}\text { Sequential TransArterial Chemoembolization and Stereotactic RadioTherapy With } \\
\text { ImmunoTherapy for Downstaging Hepatocellular Carcinoma for Hepatectomy }\end{array}$ & $\begin{array}{l}\text { Procedure: TACE } \\
\text { Radiation: SBRT } \\
\text { Drug: Immune } \\
\text { Checkpoint Inhibitor }\end{array}$ & 33 & Feb 2022 \\
\hline & NCT04268888 & Nivolumab in Combination With TACE/TAE for Patients With Intermediate Stage HCC & $\begin{array}{l}\text { Drug: Nivolumab and TACE/TAE } \\
\text { Procedure: TACE/TAE }\end{array}$ & 522 & June 2025 \\
\hline & NCT03259867 & Combination of TATE and PD-1 Inhibitor in Liver Cancer & $\begin{array}{l}\text { Drug: Opdivo Injectable Product } \\
\text { or Keytruda Injectable Product } \\
\text { Combination Product: } \\
\text { Trans-arterial } \\
\text { tirapazamine embolization }\end{array}$ & 80 & Oct 2020 \\
\hline & NCT04191889 & $\begin{array}{l}\text { A Trial of Hepatic Arterial Infusion Combined With Apatinib and Camrelizumab for C-staged } \\
\text { Hepatocellular Carcinoma in BCLC Classification }\end{array}$ & $\begin{array}{l}\text { Combination Product: Hepatic } \\
\text { Arterial Infusion combined with } \\
\text { Apatinib and Camrelizumab }\end{array}$ & 84 & Dec 2021 \\
\hline & NCT03397654 & Study of Pembrolizumab Following TACE in Primary Liver Carcinoma (PETAL) & $\begin{array}{l}\text { Drug: Pembrolizumab } \\
\text { Combination } \\
\text { Product: } \\
\text { Trans-arterial chemoembolization }\end{array}$ & 26 & Mar 2020 \\
\hline \multirow{6}{*}{$\begin{array}{l}\text { ICl + radioembolization } \\
\text { Thermal ablation } \\
\text { and radiotherapy } \\
\text { (Stage B) }\end{array}$} & NCT03033446 & Study of Y90-Radioembolization With Nivolumab in Asians With Hepatocellular Carcinoma & $\begin{array}{l}\text { Radiation: Y-90 } \\
\text { Radioembolization } \\
\text { Drug: Nivolumab }\end{array}$ & 40 & Dec 2019 \\
\hline & NCT03380130 & $\begin{array}{l}\text { A Study of the Safety and Antitumoral Efficacy of Nivolumab After SIRT for the Treatment of } \\
\text { Patients With HCC (NASIR-HCC) }\end{array}$ & $\begin{array}{l}\text { Drug: Nivolumab } \\
\text { Device: SIR-Spheres }\end{array}$ & 40 & Oct 2019 \\
\hline & NCT03753659 & $\begin{array}{l}\text { IMMULAB - Immunotherapy With Pembrolizumab in Combination With Local Ablation } \\
\text { in Hepatocellular Carcinoma (HCC) }\end{array}$ & $\begin{array}{l}\text { Drug: Pembrolizumab } \\
\text { Procedure: Radio Frequency } \\
\text { Ablation (RFA) } \\
\text { Procedure: Microwave Ablation } \\
\text { (MWA) } \\
\text { (and } 2 \text { more...) }\end{array}$ & 30 & Mar 2022 \\
\hline & NCT04193696 & RT+ Anti-PD-1 for Patients With Advanced HCC (RT+PD-1-HCC) & $\begin{array}{l}\text { Drug: Radiation therapy and } \\
\text { systemic anti-PD-1 } \\
\text { immunotherapy for patients with } \\
\text { advanced } \\
\text { hepatocellular carcinoma }\end{array}$ & 39 & June 2020 \\
\hline & NCT03864211 & Thermal Ablation Followed by Immunotherapy for HCC & $\begin{array}{l}\text { Procedure: Thermal ablation } \\
\text { Drug: Toriplimab }\end{array}$ & 120 & Mar 2021 \\
\hline & NCT04167293 & $\begin{array}{l}\text { Combination of Sintilimab and Stereotactic Body Radiotherapy in Hepatocellular } \\
\text { Carcinoma (ISBRT01) }\end{array}$ & $\begin{array}{l}\text { Radiation: stereotactic body } \\
\text { radiotherapy } \\
\text { Drug: Sintilimab }\end{array}$ & 116 & Nov 2021 \\
\hline
\end{tabular}


TABLE 1 | Continued

\begin{tabular}{|c|c|c|c|c|c|}
\hline Immunotherapy & Identifier & Study title & Interventions & Number enrolled & $\begin{array}{l}\text { Primary } \\
\text { completion }\end{array}$ \\
\hline & NCT03316872 & Study of Pembrolizumab and Radiotherapy in Liver Cancer & $\begin{array}{l}\text { Drug: Pembrolizumab } \\
\text { Radiation: Stereotactic Body } \\
\text { Radiotherapy (SBRT) }\end{array}$ & 30 & Apr 2020 \\
\hline \multirow[t]{2}{*}{ Monotherapy Stage C) } & NCT01693562 & A Phase $1 / 2$ Study to Evaluate MEDI4736 & Drug: MEDI4736 & 1022 & Feb 2020 \\
\hline & NCT03389126 & $\begin{array}{l}\text { Phase II Study of Avelumab in Patients With Advanced Hepatocellular Carcinoma After Prior } \\
\text { Sorafenib Treatment (Avelumab HCC) }\end{array}$ & Drug: Avelumab & 30 & Dec 2019 \\
\hline \multirow[t]{11}{*}{$\begin{array}{l}\mathrm{ICl}+\mathrm{TKi} \\
\text { (Stage C) }\end{array}$} & NCT01658878 & $\begin{array}{l}\text { An Immuno-therapy Study to Evaluate the Effectiveness, Safety and Tolerability of } \\
\text { Nivolumab or Nivolumab in Combination With Other Agents in Patients With Advanced } \\
\text { Liver Cancer }\end{array}$ & $\begin{array}{l}\text { Biological: Nivolumab } \\
\text { Drug: Sorafenib } \\
\text { Drug: Ipilimumab } \\
\text { Drug: Cabozantinib }\end{array}$ & 1097 & Aug 2020 \\
\hline & NCT03841201 & $\begin{array}{l}\text { Immunotherapy With Nivolumab in Combination With Lenvatinib for Advanced Stage } \\
\text { Hepatocellular Carcinoma }\end{array}$ & $\begin{array}{l}\text { Drug: Lenvatinib } \\
\text { Drug: Nivolumab }\end{array}$ & 50 & July 2021 \\
\hline & NCT04183088 & $\begin{array}{l}\text { Regorafenib Plus Tislelizumab as First-line Systemic Therapy for Patients With Advanced } \\
\text { Hepatocellular Carcinoma }\end{array}$ & $\begin{array}{l}\text { Drug: Tislelizumab+ } \\
\text { regorafenib for part } \\
1 ; \text { Tislelizumab+ } \\
\text { regorafenib for group } 1 \text { of part } 2 \text {; } \\
\text { Placebo+regorafenib for group } 2 \\
\text { of part } 2 \text {. }\end{array}$ & 125 & Mar 2024 \\
\hline & NCT04310709 & Combination of Regorafenib and Nivolumab in Unresectable Hepatocellular Carcinoma & Drug: Regorafenib/Nivolumab & 42 & May 2022 \\
\hline & NCT03439891 & $\begin{array}{l}\text { Sorafenib and Nivolumab in Treating Participants With Unresectable, Locally Advanced or } \\
\text { Metastatic Liver Cancer }\end{array}$ & $\begin{array}{l}\text { Other: Laboratory Biomarker } \\
\text { Analysis } \\
\text { Biological: Nivolumab } \\
\text { Drug: Sorafenib }\end{array}$ & 40 & Sept 2022 \\
\hline & NCT03170960 & $\begin{array}{l}\text { Study of Cabozantinib in Combination With Atezolizumab to Subjects With Locally } \\
\text { Advanced or Metastatic Solid Tumors }\end{array}$ & $\begin{array}{l}\text { Drug: cabozantinib } \\
\text { Drug: atezolizumab }\end{array}$ & 1732 & Dec 2020 \\
\hline & NCT03899428 & $\begin{array}{l}\text { Immune Checkpoint Therapy vs. Target Therapy in Reducing Serum HBsAg Levels in } \\
\text { Patients With HBsAg + Advanced Stage HCC }\end{array}$ & $\begin{array}{l}\text { Drug: Durvalumab } \\
\text { Drug: Sorafenib } \\
\text { Drug: Lenvatinib } \\
\text { (and } 2 \text { more...) }\end{array}$ & 30 & Dec 2021 \\
\hline & NCT04442581 & Cabozantinib and Pembrolizumab for the First-Line Treatment of Advanced Liver Cancer & $\begin{array}{l}\text { Drug: Cabozantinib S-malate } \\
\text { Biological: Pembrolizumab }\end{array}$ & 29 & Sept 2023 \\
\hline & NCT04523662 & $\begin{array}{l}\text { Study on the Effectiveness and Safety of Carrelizumab Combined With Apatinib Mesylate } \\
\text { and Radiotherapy in the Treatment of Advanced Liver Cancer }\end{array}$ & $\begin{array}{l}\text { Drug: Camrelizumab } \\
\text { Apatinib Mesylas }\end{array}$ & 27 & Aug 2022 \\
\hline & NCT04212221 & $\begin{array}{l}\text { MGD013 Monotherapy and Combination With Brivanib Dose Escalation and Expansion } \\
\text { Study in Advanced Liver Cancer Patients }\end{array}$ & $\begin{array}{l}\text { Drug: MGD013 monotherapy } \\
\text { Drug: MGD013 in combination } \\
\text { with Brivanib Alaninate }\end{array}$ & 300 & Dec 2022 \\
\hline & NCT03463876 & $\begin{array}{l}\text { A Trial of SHR-1210 (an Anti-PD-1 Inhibitor) in Combination With Apatinib in Patients With } \\
\text { Advanced HCC(RESCUE) }\end{array}$ & Drug: SHR 1210+apatinib & 190 & June 2019 \\
\hline $\mathrm{ICl}+\mathrm{ICl}$ & NCT03228667 & $\begin{array}{l}\text { QUILT-3.055: A Study of Combination Immunotherapies in Patients Who Have Previously } \\
\text { Received Treatment With Immune Checkpoint Inhibitors }\end{array}$ & $\begin{array}{l}\text { Drug: } \mathrm{N}-803 \text { + Pembrolizumab } \\
\text { Drug: N-803 + Nivolumab } \\
\text { Drug: } \mathrm{N}-803 \text { + Atezolizumab } \\
\text { (and } 7 \text { more...) }\end{array}$ & 636 & June 2021 \\
\hline
\end{tabular}


TABLE 1 | Continued

\begin{tabular}{|c|c|c|c|c|c|}
\hline Immunotherapy & Identifier & Study title & Interventions & Number enrolled & $\begin{array}{l}\text { Primary } \\
\text { completion }\end{array}$ \\
\hline & NCT03311334 & $\begin{array}{l}\text { A Study of DSP-7888 Dosing Emulsion in Combination With Immune Checkpoint } \\
\text { Inhibitors in Adult Patients With Advanced Solid Tumors }\end{array}$ & $\begin{array}{l}\text { Drug: DSP-7888 Dosing } \\
\text { Emulsion } \\
\text { Drug: Nivolumab } \\
\text { Drug: Pembrolizumab }\end{array}$ & 84 & Nov 2021 \\
\hline & NCT03228667 & $\begin{array}{l}\text { QUILT-3.055: A Study of Combination Immunotherapies in Patients Who Have Previously } \\
\text { Received Treatment With Immune Checkpoint Inhibitors }\end{array}$ & $\begin{array}{l}\text { Drug: N-803 + Pembrolizumab } \\
\text { Drug: N-803 + Nivolumab } \\
\text { Drug: N-803 + Atezolizumab } \\
\text { (and } 7 \text { more...) }\end{array}$ & 636 & June 2021 \\
\hline & NCT04430452 & $\begin{array}{l}\text { Hypofractionated Radiotherapy Followed by Durvalumab With or Without Tremelimumab } \\
\text { for the Treatment of Liver Cancer After Progression on Prior PD-1 Inhibition }\end{array}$ & $\begin{array}{l}\text { Biological: Durvalumab } \\
\text { Radiation: Hypofractionated } \\
\text { Radiation Therapy } \\
\text { Biological: Tremelimumab }\end{array}$ & 30 & Aug 2022 \\
\hline & NCT04547452 & $\begin{array}{l}\text { Combination of Sintilimab and Stereotactic Body Radiotherapy in Advanced } \\
\text { Metastatic HCC }\end{array}$ & $\begin{array}{l}\text { Radiation: Stereotactic body } \\
\text { radiation therapy } \\
\text { Drug: Anti-PD-1 antibody drug } \\
\text { named Sintilimab }\end{array}$ & 84 & July 2022 \\
\hline & NCT03655613 & $\begin{array}{l}\text { APL-501 or Nivolumab in Combination With APL-101 in Locally Advanced or Metastatic } \\
\text { HCC and RCC }\end{array}$ & $\begin{array}{l}\text { Biological: APL-501 } \\
\text { Drug: APL-101 } \\
\text { Biological: Nivolumab }\end{array}$ & 119 & Sept 2020 \\
\hline & NCT04380545 & $\begin{array}{l}\text { Nivolumab, Fluorouracil, and Interferon Alpha 2B for the Treatment of Unresectable } \\
\text { Fibrolamellar Cancer }\end{array}$ & $\begin{array}{l}\text { Drug: Fluorouracil } \\
\text { Biological: Nivolumab } \\
\text { Biological: Recombinant } \\
\text { Interferon Alpha 2b-like Protein }\end{array}$ & 15 & July 2021 \\
\hline & NCT02519348 & $\begin{array}{l}\text { A Study of Durvalumab or Tremelimumab Monotherapy, or Durvalumab in Combination } \\
\text { With Tremelimumab or Bevacizumab in Advanced Hepatocellular Carcinoma }\end{array}$ & $\begin{array}{l}\text { Biological: Durvalumab + } \\
\text { tremelimumab } \\
\text { Biological: Durvalumab } \\
\text { Biological: Tremelimumab } \\
\text { Biological: Durvalumab } \\
\text { + Bevacizumab }\end{array}$ & 433 & Nov 2020 \\
\hline & NCT03755739 & $\begin{array}{l}\text { Trans-Artery/Intra-Tumor Infusion of Checkpoint Inhibitors for Immunotherapy of Advanced } \\
\text { Solid Tumors }\end{array}$ & $\begin{array}{l}\text { Drug: Checkpoint inhibitor (CPI) } \\
\text { such as Pembrolizumab }\end{array}$ & 200 & Nov 2033 \\
\hline & NCT02940496 & $\begin{array}{l}\text { Pembrolizumab With or Without Elbasvir/Grazoprevir and Ribavirin in Treating Patients } \\
\text { With Advanced Refractory Liver Cancer }\end{array}$ & $\begin{array}{l}\text { Drug: Elbasvir/Grazoprevir } \\
\text { Other: Laboratory Biomarker } \\
\text { Analysis } \\
\text { Biological: Pembrolizumab } \\
\text { Drug: Ribavirin }\end{array}$ & 30 & Dec 2021 \\
\hline & NCT03836352 & $\begin{array}{l}\text { Study of an Immunotherapeutic, DPX-Survivac, in Combination With Low Dose } \\
\text { Cyclophosphamide \& Pembrolizumab, in Subjects With Selected Advanced \& Recurrent } \\
\text { Solid Tumors }\end{array}$ & $\begin{array}{l}\text { Other: DPX-Survivac } \\
\text { Drug: Cyclophosphamide } \\
\text { Drug: Pembrolizumab }\end{array}$ & 184 & Dec 2022 \\
\hline
\end{tabular}




\begin{tabular}{|c|c|c|c|c|c|}
\hline Immunotherapy & Identifier & Study title & Interventions & Number enrolled & $\begin{array}{l}\text { Primary } \\
\text { completion }\end{array}$ \\
\hline & NCT03544723 & $\begin{array}{l}\text { Safety and Efficacy of p53 Gene Therapy Combined With Immune Checkpoint Inhibitors in } \\
\text { Solid Tumors. }\end{array}$ & Drug: Ad-p53 & 40 & June 2022 \\
\hline & NCT03680508 & $\begin{array}{l}\text { TSR-022 (Anti-TIM-3 Antibody) and TSR-042 (Anti-PD-1 Antibody) in Patients With } \\
\text { Liver Cancer }\end{array}$ & Drug: TSR-022 and TSR-042 & 42 & Oct 2022 \\
\hline \multirow[t]{3}{*}{$C A R-T$} & NCT03941626 & Autologous CAR-T/TCR-T Cell Immunotherapy for Solid Malignancies & $\begin{array}{l}\text { Biological: CAR-T/TCR-T } \\
\text { cells immunotherapy }\end{array}$ & 50 & Dec 2020 \\
\hline & NCT03638206 & Autologous CAR-T/TCR-T Cell Immunotherapy for Malignancies & $\begin{array}{l}\text { Biological: CAR-T } \\
\text { cell immunotherapy }\end{array}$ & 73 & Mar 2023 \\
\hline & NCT03013712 & A Clinical Research of CAR T Cells Targeting EpCAM Positive Cancer & $\begin{array}{l}\text { Biological: CAR-T } \\
\text { cell immunotherapy }\end{array}$ & 60 & Dec 2018 \\
\hline \multirow[t]{4}{*}{$A C T$} & NCT03093688 & $\begin{array}{l}\text { Clinical Safety and Efficacy Study of Infusion of iNKT Cells and CD8+T Cells in Patients } \\
\text { With Advanced Solid Tumor }\end{array}$ & $\begin{array}{l}\text { Biological: Infusion of iNKT cells } \\
\text { and CD8+T cells }\end{array}$ & 40 & Dec 2021 \\
\hline & NCT04502082 & Study of ET140203 T Cells in Adults With Advanced Hepatocellular Carcinoma (ARYA-1) & $\begin{array}{l}\text { Biological: ET140203 autologous } \\
\text { T cell product }\end{array}$ & 50 & Jan 2023 \\
\hline & NCT03998033 & Study of ET140202 T Cells in Adults With Advanced Hepatocellular Carcinoma & $\begin{array}{l}\text { Biological: ET140202 autologous } \\
\text { T cell product }\end{array}$ & 50 & July 2022 \\
\hline & NCT03592706 & Autologous Immune Killer Cells to Treat Liver Cancer Patients as an Adjunct Therapy & $\begin{array}{l}\text { Biological: IKC (Immune Killer } \\
\text { Cells) Procedure: TACE } \\
\text { (Transcatheter } \\
\text { Arterial Chemoembolization) }\end{array}$ & 60 & Feb 2021 \\
\hline & NCT02856815 & Safety and Efficacy of "Immune Cell-LC" in TACE Therapy & Biological: Immuncell-LC & 78 & October 30, 2020 \\
\hline ov & NCT03071094 & $\begin{array}{l}\text { A Trial to Evaluate the Safety and Efficacy of the Combination of the Oncolytic } \\
\text { Immunotherapy Pexa-Vec With the PD-1 Receptor Blocking Antibody Nivolumab in the } \\
\text { First-line Treatment of Advanced Hepatocellular Carcinoma (HCC) }\end{array}$ & $\begin{array}{l}\text { Biological: Pexastimogene } \\
\text { Devacirepvec (Pexa Vec) } \\
\text { Drug: Nivolumab }\end{array}$ & 30 & Sept 2020 \\
\hline Vax & NCT03067493 & RFA Combined With Neo-MASCT for Primary HCC: a Phase II Trial & Biological: Neo-MASCT & 98 & Mar 2021 \\
\hline \multicolumn{6}{|l|}{ Phase I clinical trials } \\
\hline \multicolumn{6}{|l|}{ ICI + combinations } \\
\hline Neoadjuvant (Stage A) & NCT03682276 & $\begin{array}{l}\text { Safety and Bioactivity of Ipilimumab and Nivolumab Combination Prior to Liver Resection } \\
\text { in Hepatocellular Carcinoma }\end{array}$ & $\begin{array}{l}\text { Biological: Ipilimumab } \\
\text { Biological: Nivolumab }\end{array}$ & 32 & Dec 2020 \\
\hline$I C I+$ TACE (Stage B) & NCT03143270 & $\begin{array}{l}\text { A Study to Test the Safety and Feasibility of Nivolumab With Drug Eluting Bead Transarterial } \\
\text { Chemoembolization in Patients With Liver Cancer }\end{array}$ & $\begin{array}{l}\text { Drug: Drug Eluting Bead } \\
\text { Transarterial Chemoembolization } \\
\text { Drug: Nivolumab }\end{array}$ & 14 & Apr 2022 \\
\hline \multirow[t]{2}{*}{$\begin{array}{l}\text { ICI + radioembolization } \\
\text { (Stage } B \text { ) }\end{array}$} & NCT03099564 & Pembrolizumab Plus Y90 Radioembolization in HCC Subjects & $\begin{array}{l}\text { Drug: Pembrolizumab } \\
\text { Device: Y90 radioembolization }\end{array}$ & 30 & July 2020 \\
\hline & NCT02837029 & $\begin{array}{l}\text { Nivolumab and Yttrium Y } 90 \text { Glass Microspheres in Treating Patients With Advanced } \\
\text { Liver Cancer }\end{array}$ & $\begin{array}{l}\text { Other: Laboratory Biomarker } \\
\text { Analysis } \\
\text { Biological: Nivolumab } \\
\text { Radiation: Yttrium Y } 90 \\
\text { Glass Microspheres }\end{array}$ & 27 & July 2019 \\
\hline
\end{tabular}


TABLE 1 | Continued

\begin{tabular}{|c|c|c|c|c|c|}
\hline Immunotherapy & Identifier & Study title & Interventions & Number enrolled & $\begin{array}{l}\text { Primary } \\
\text { completion }\end{array}$ \\
\hline & NCT01658878 & $\begin{array}{l}\text { An Immuno-therapy Study to Evaluate the Effectiveness, Safety and Tolerability of } \\
\text { Nivolumab or Nivolumab in Combination With Other Agents in Patients With Advanced } \\
\text { Liver Cancer }\end{array}$ & $\begin{array}{l}\text { Biological: Nivolumab } \\
\text { Drug: Sorafenib } \\
\text { Drug: Ipilimumab } \\
\text { Drug: Cabozantinib }\end{array}$ & 1097 & Aug 2020 \\
\hline & NCT03474640 & $\begin{array}{l}\text { Safety, Tolerability and Pharmacokinetics of an Anti-PD-1 Monoclonal Antibody in } \\
\text { Subjects With Advanced Malignancies }\end{array}$ & $\begin{array}{l}\text { Biological: Toripalimab, } \\
\text { Recombinant Humanized } \\
\text { anti-PD-1 Monoclonal Antibody }\end{array}$ & 258 & Aug 2022 \\
\hline & NCT03655613 & $\begin{array}{l}\text { APL-501 or Nivolumab in Combination With APL-101 in Locally Advanced or Metastatic } \\
\text { HCC and RCC }\end{array}$ & $\begin{array}{l}\text { Biological: APL-501 } \\
\text { Drug: APL-101 } \\
\text { Biological: Nivolumab }\end{array}$ & 119 & Sept 2020 \\
\hline & NCT04564313 & $\begin{array}{l}\text { Safety and Efficacy of Camrelizumab (Anti-PD-1 Antibody) in Recurrent HCC After } \\
\text { Liver Transplantation }\end{array}$ & Drug: Camrelizumab treatment & 20 & July 2021 \\
\hline & NCT02940496 & $\begin{array}{l}\text { Pembrolizumab With or Without Elbasvir/Grazoprevir and Ribavirin in Treating Patients } \\
\text { With Advanced Refractory Liver Cancer }\end{array}$ & $\begin{array}{l}\text { Drug: Elbasvir/Grazoprevir } \\
\text { Other: Laboratory Biomarker } \\
\text { Analysis } \\
\text { Biological: Pembrolizumab } \\
\text { Drug: Ribavirin }\end{array}$ & 30 & Dec 2021 \\
\hline & NCT03203304 & Stereotactic Body Radiotherapy (SBRT) Followed by Immunotherapy in Liver Cancer & $\begin{array}{l}\text { Drug: Nivolumab } \\
\text { Drug: Ipilimumab }\end{array}$ & 50 & Aug 2021 \\
\hline & NCT04220944 & Combined Locoregional Treatment With Immunotherapy for Unresectable HCC. & $\begin{array}{l}\text { Drug: Sintilimab } \\
\text { Procedure: Microwave Ablation } \\
\text { Procedure: TACE }\end{array}$ & 45 & June 2021 \\
\hline & NCT03864211 & Thermal Ablation Followed by Immunotherapy for HCC & $\begin{array}{l}\text { Procedure: Thermal ablation } \\
\text { Drug: Toriplimab }\end{array}$ & 120 & Mar 2021 \\
\hline New ICI & NCT04374877 & Study of SRF388 in Patients With Advanced Solid Tumors & Drug: SRF388 & 122 & July 2021 \\
\hline \multirow[t]{6}{*}{ CAR-T } & NCT04121273 & GPC3-targeted CAR-T Cell for Treating GPC3 Positive Advanced HCC & $\begin{array}{l}\text { Biological: CAR-T } \\
\text { cell immunotherapy }\end{array}$ & 20 & Oct 2021 \\
\hline & NCT02905188 & $\begin{array}{l}\text { Glypican 3-specific Chimeric Antigen Receptor Expressing T Cells for Hepatocellular } \\
\text { Carcinoma (GLYCAR) }\end{array}$ & $\begin{array}{l}\text { Genetic: GLYCAR T cells } \\
\text { Drug: Cytoxan } \\
\text { Drug: Fludarabine }\end{array}$ & 14 & Dec 2021 \\
\hline & NCT03198546 & GPC3-T2-CAR-T Cells for Immunotherapy of Cancer With GPC3 Expression & $\begin{array}{l}\text { Biological: GPC3 and/or TGF } \beta \\
\text { targeting CAR-T cells }\end{array}$ & 30 & Aug 2020 \\
\hline & NCT03941626 & Autologous CAR-T/TCR-T Cell Immunotherapy for Solid Malignancies & $\begin{array}{l}\text { Biological: CAR-T/TCR-T } \\
\text { cells immunotherapy }\end{array}$ & 50 & Dec 2020 \\
\hline & NCT03638206 & Autologous CAR-T/TCR-T Cell Immunotherapy for Malignancies & $\begin{array}{l}\text { Biological: CAR-T } \\
\text { cell immunotherapy }\end{array}$ & 73 & Mar 2023 \\
\hline & NCT03013712 & A Clinical Research of CAR T Cells Targeting EpCAM Positive Cancer & $\begin{array}{l}\text { Biological: CAR-T } \\
\text { cell immunotherapy }\end{array}$ & 60 & Dec 2018 \\
\hline
\end{tabular}


TABLE 1 | Continued

\begin{tabular}{|c|c|c|c|c|c|}
\hline Immunotherapy & Identifier & Study title & Interventions & Number enrolled & $\begin{array}{l}\text { Primary } \\
\text { completion }\end{array}$ \\
\hline \multirow[t]{8}{*}{$A C T$} & NCT03093688 & $\begin{array}{l}\text { Clinical Safety and Efficacy Study of Infusion of iNKT Cells and CD8+T Cells in Patients } \\
\text { With Advanced Solid Tumor }\end{array}$ & $\begin{array}{l}\text { Biological: Infusion of iNKT cells } \\
\text { and CD8+T cells }\end{array}$ & 40 & Dec 2021 \\
\hline & NCT04032392 & Immunotherapy of Advanced Hepatitis B Related Hepatocellular Carcinoma With $\gamma \delta$ T Cells & Biological: autologous $\gamma \delta$ T cells & 20 & July 2021 \\
\hline & NCT04502082 & Study of ET140203T Cells in Adults With Advanced Hepatocellular Carcinoma (ARYA-1) & $\begin{array}{l}\text { Biological: ET140203 autologous } \\
\text { T cell product }\end{array}$ & 50 & Jan 2023 \\
\hline & NCT03998033 & Study of ET140202T Cells in Adults With Advanced Hepatocellular Carcinoma & $\begin{array}{l}\text { Biological: ET140202 autologous } \\
\text { T cell product }\end{array}$ & 50 & July 2022 \\
\hline & NCT03132792 & $\mathrm{AFP}^{\mathrm{c} 332} \mathrm{~T}$ in Advanced $\mathrm{HCC}$ & $\begin{array}{l}\text { Genetic: Autologous genetically } \\
\text { modified AFPc } 332 \mathrm{~T} \text { cells }\end{array}$ & 45 & June 2021 \\
\hline & NCT03441100 & TCR-engineered T Cells in Solid Tumors: IMA202-101 & $\begin{array}{l}\text { Drug: IMA202 Product } \\
\text { Device: IMA_Detect }\end{array}$ & 15 & June 2022 \\
\hline & NCT03319459 & $\begin{array}{l}\text { FATE-NK100 as Monotherapy and in Combination With Monoclonal Antibody in Subjects } \\
\text { With Advanced Solid Tumors }\end{array}$ & $\begin{array}{l}\text { Drug: FATE-NK100 } \\
\text { Drug: Cetuximab } \\
\text { Drug: Trastuzumab }\end{array}$ & 100 & Oct 2021 \\
\hline & NCT03841110 & $\begin{array}{l}\text { FT500 as Monotherapy and in Combination With Immune Checkpoint Inhibitors in Subjects } \\
\text { With Advanced Solid Tumors }\end{array}$ & $\begin{array}{l}\text { Drug: FT500 } \\
\text { Drug: Nivolumab } \\
\text { Drug: Pembrolizumab } \\
\text { (and } 3 \text { more...) }\end{array}$ & 76 & Mar 2022 \\
\hline \multirow[t]{2}{*}{ Agonists/Cytokines } & NCT02315066 & $\begin{array}{l}\text { Study Of OX40 Agonist PF-04518600 Alone And In Combination With 4-1BB Agonist } \\
\text { PF-05082566 }\end{array}$ & $\begin{array}{l}\text { Drug: PF-04518600 } \\
\text { Drug: PF-04518600 } \\
\text { plus PF-05082566 }\end{array}$ & 176 & Dec 2020 \\
\hline & NCT03655002 & $\begin{array}{l}\text { IRX-2, Cyclophosphamide, and Nivolumab in Treating Patients With Recurrent or Metastatic } \\
\text { and Refractory Liver Cancer }\end{array}$ & $\begin{array}{l}\text { Drug: Cyclophosphamide } \\
\text { Biological: Cytokine-based } \\
\text { Biologic Agent IRX-2 } \\
\text { Biological: Nivolumab }\end{array}$ & 28 & June 2022 \\
\hline ov & NCT03071094 & $\begin{array}{l}\text { A Trial to Evaluate the Safety and Efficacy of the Combination of the Oncolytic } \\
\text { Immunotherapy Pexa-Vec With the PD-1 Receptor Blocking Antibody Nivolumab in the } \\
\text { First-line Treatment of Advanced Hepatocellular Carcinoma (HCC) }\end{array}$ & $\begin{array}{l}\text { Biological: Pexastimogene } \\
\text { Devacirepvec (Pexa Vec) } \\
\text { Drug: Nivolumab }\end{array}$ & 30 & Sept 2020 \\
\hline Vax & NCT04248569 & $\begin{array}{l}\text { DNAJB1-PRKACA Fusion Kinase Peptide Vaccine Combined With Nivolumab and } \\
\text { Ipilimumab for Patients With Fibrolamellar Hepatocellular Carcinoma }\end{array}$ & $\begin{array}{l}\text { Drug: DNAJB1-PRKACA peptide } \\
\text { vaccine } \\
\text { Drug: Nivolumab } \\
\text { Drug: Ipilimumab }\end{array}$ & 12 & Mar 2024 \\
\hline
\end{tabular}




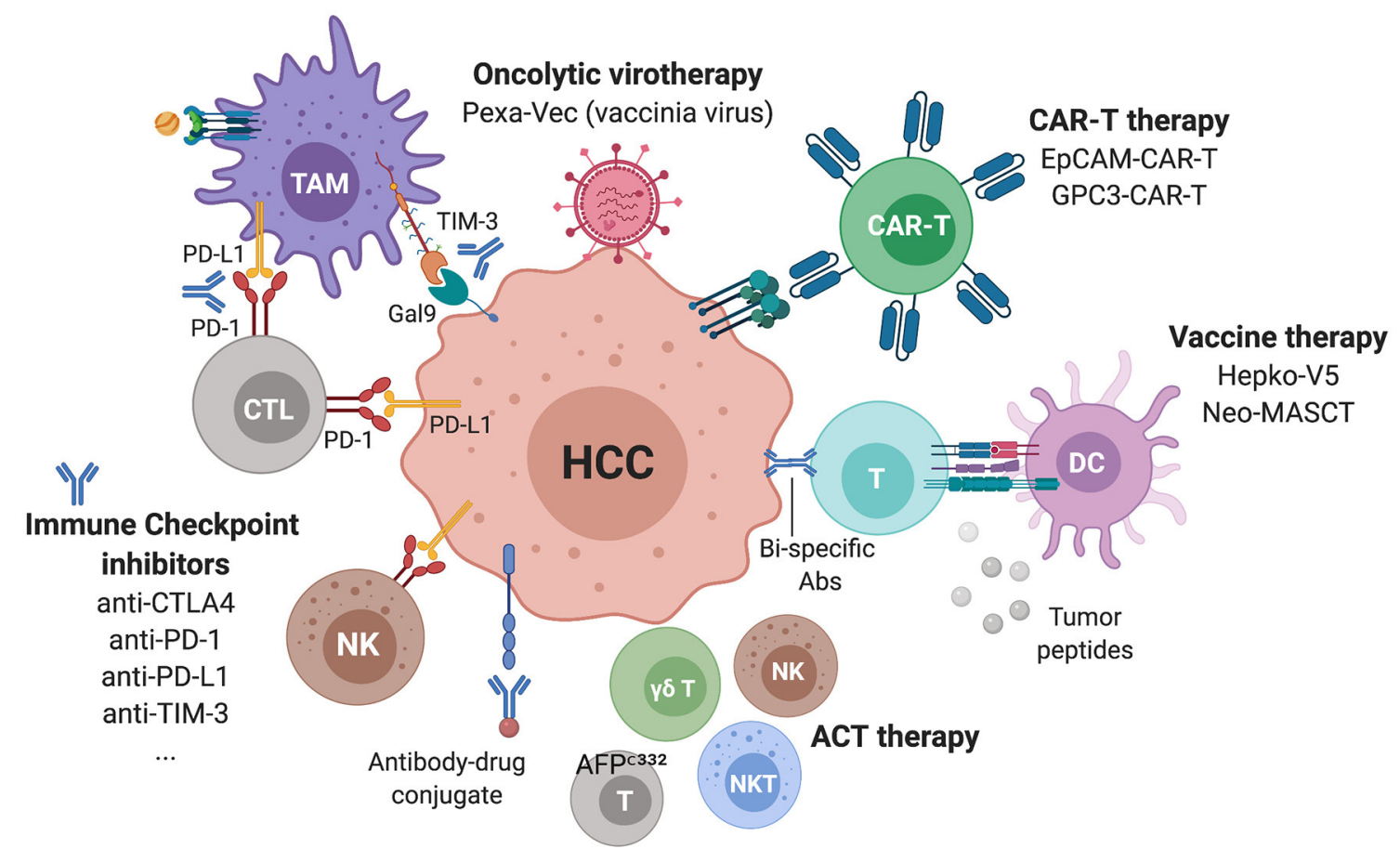

FIGURE 6 | Immunotherapies in ongoing clinical trials for advanced HCC. Several ICls targeting checkpoints on lymphocytes but also NK and myeloid cells are currently being assessed as monotherapies or in combinations. Additional strategies include CAR-T cells, oncolytic viruses, vaccines, antibody-drug conjugates and bi-specific antibodies.

in a phase I/II trial (NCT03013712). In a similar approach, a phase I trial is testing the transfer of autologous genetically modified $\mathrm{AFP}^{\mathrm{c} 332} \mathrm{~T}$ cells, $\mathrm{T}$ cells expressing an enhanced TCR Specific for $\alpha$-fetoprotein in HLA-A2 positive patients with advanced HCC (NCT03132792). In the oncolytic viruses sphere, a phase III trial (NCT02562755) is testing a vaccinia virusbased immunotherapy, Pexastimogene Devacirepvec (Pexa-Vec), in patients with advanced HCC, based on promising results from the phase IIb trial TRAVERSE (128). Pexa-Vec is also being tested in combination with nivolumab in the first-line treatment of advanced HCC in a phase II trial (NCT03071094). As for vaccines, a phase III trial (NCT02232490) is evaluating the benefit of hepcortespenlisimut-L (Hepko-V5), an oral allogeneic vaccine derived from patients' blood, given in an experimental arm vs. placebo, to patients with advanced HCC. Similarly, a phase II trial (NCT03067493) is testing the Neoantigen Multiple Target Antigen Stimulating Cell Therapy (Neo-MASCT) vaccine, which consists of 18 cycles, each including one DC subcutaneous injection and one CTL infusion.

\section{CONCLUSIONS}

HCC comprises a heterogeneous set of cancers with different etiologies, mutations and immune microenvironments, as demonstrated by broad molecular and immunological classifications. The advent of recent technologies including single cell approaches is now allowing high resolution characterization of the immune landscapes of HCC and is expected to uncover novel immunotherapeutic targets and approaches tailored to patients. ICI combination therapies are expected to dramatically improve the systemic therapy of advanced HCC. However, the prioritization of different combinations requires additional understanding of liver-specific immunity and the validation of therapeutic targets in suitable pre-clinical models of HCC taking into consideration the genetic heterogeneity of tumor cells and the cirrhotic or NASH environments. Further, an in-depth characterization of the biomarkers leading to improved patients' response to the various such combinations will contribute to better selection of patients and ameliorate the outcome. Last, a critical issue not discussed here is the management of immunerelated adverse events (irAEs) often elicited by immunotherapies and that should be considered in designing and implementing immunotherapies. It is hoped that with the rapidly evolving field of oncoimmunology and trials in different cancer types, we will learn valuable lessons for future drug discovery in HCC.

\section{AUTHOR CONTRIBUTIONS}

JG and MS conceived the structure of this review. DC contributed to the description of the immune landscape of the liver and of HCC and prepared Figure 3. J-FB contributed to the review of clinical activity in HCC. All authors revised the manuscript and approved the final version. 


\section{FUNDING}

MS is funded by grants from the ARC foundation, IDEX Bordeaux, SIRIC BRIO and The New Aquitaine Region.

\section{REFERENCES}

1. Shetty S, Lalor PF, Adams DH. Liver sinusoidal endothelial cells - gatekeepers of hepatic immunity. Nat Rev Gastroenterol Hepatol. (2018) 15:55567. doi: 10.1038/s41575-018-0020-y

2. Global Burden of Disease Cancer C. Global, regional, and national cancer incidence, mortality, years of life lost, years lived with disability, and disability-Adjusted life-Years for 29 cancer groups:1990 to 2017: a Systematic analysis for the global burden of disease study. JAMA Oncol. (2019) 5:1749-68. doi: 10.1001/jamaoncol.2019.2996

3. Yang JD, Hainaut P, Gores GJ, Amadou A, Plymoth A, Roberts LR. A global view of hepatocellular carcinoma: trends, risk, prevention and management. Nat Rev Gastroenterol Hepatol. (2019) 16:589-604. doi: 10.1038/s41575-019-0186-y

4. Muller M, Bird TG, Nault JC. The landscape of gene mutations in cirrhosis and hepatocellular carcinoma. J Hepatol. (2020) 72:9901002. doi: 10.1016/j.jhep.2020.01.019

5. Anstee QM, Reeves HL, Kotsiliti E, Govaere O, Heikenwalder M. From nASH to hCC: current concepts and future challenges. Nat Rev Gastroenterol Hepatol. (2019) 16:411-28. doi: 10.1038/s41575-019-0145-7

6. Bruix J, Reig M, Sherman M. Evidence-Based diagnosis, staging, and treatment of patients with hepatocellular carcinoma. Gastroenterology. (2016) 150:835-53. doi: 10.1053/j.gastro.2015.12.041

7. Llovet JM, Ricci S, Mazzaferro V, Hilgard P, Gane E, Blanc JF, et al. Sorafenib in advanced hepatocellular carcinoma. $N$ Engl J Med. (2008) 359:378-90. doi: 10.1056/NEJMoa0708857

8. Kudo M, Finn RS, Qin S, Han KH, Ikeda K, Piscaglia F, et al. Lenvatinib versus sorafenib in first-line treatment of patients with unresectable hepatocellular carcinoma: a randomised phase 3 non-inferiority trial. Lancet. (2018) 391:1163-73. doi: 10.1016/S0140-6736(18)30207-1

9. Vogel A, Cervantes A, Chau I, Daniele B, Llovet JM, Meyer T, et al. Hepatocellular carcinoma: eSMO clinical practice guidelines for diagnosis, treatment and follow-up. Ann Oncol. (2018) 29:iv238-55. doi: 10.1093/annonc/mdy308

10. Cheng AL, Kang YK, Chen Z, Tsao CJ, Qin S, Kim JS, et al. Efficacy and safety of sorafenib in patients in the Asia-Pacific region with advanced hepatocellular carcinoma: a phase III randomised, double-blind, placebo-controlled trial. Lancet Oncol. (2009) 10:25-34. doi: 10.1016/S1470-2045(08)70285-7

11. Reig M, Torres F, Rodriguez-Lope C, Forner A, N LL, Rimola J, et al. Early dermatologic adverse events predict better outcome in hCC patients treated with sorafenib. J Hepatol. (2014) 61:318-24. doi: 10.1016/j.jhep.2014.03.030

12. Bruix J, Qin S, Merle P, Granito A, Huang YH, Bodoky G, et al. Regorafenib for patients with hepatocellular carcinoma who progressed on sorafenib treatment (RESORCE): a randomised, double-blind, placebo-controlled, phase 3 trial. Lancet. (2017) 389:56-66. doi: 10.1016/S0140-6736(16)32453-9

13. Abou-Alfa GK, Meyer T, Cheng AL, El-Khoueiry AB, Rimassa L, Ryoo BY, et al. Cabozantinib in patients with advanced and progressing hepatocellular carcinoma. N Engl J Med. (2018) 379:54-63. doi: 10.1056/NEJMoa1717002

14. Spratlin JL, Cohen RB, Eadens M, Gore L, Camidge DR, Diab S, et al. Phase I pharmacologic and biologic study of ramucirumab (IMC-1121B), a fully human immunoglobulin G1 monoclonal antibody targeting the vascular endothelial growth factor receptor-2. J Clin Oncol. (2010) 28:7807. doi: 10.1200/JCO.2009.23.7537

15. El-Khoueiry AB, Sangro B, Yau T, Crocenzi TS, Kudo M, Hsu $\mathrm{C}$, et al. Nivolumab in patients with advanced hepatocellular carcinoma (CheckMate 040): an open-label, non-comparative, phase $1 / 2$ dose escalation and expansion trial. Lancet. (2017) 389:2492-502. doi: 10.1016/S0140-6736(17)31046-2

\section{SUPPLEMENTARY MATERIAL}

The Supplementary Material for this article can be found online at: https://www.frontiersin.org/articles/10.3389/fimmu. 2021.655697/full\#supplementary-material

16. Zhu AX, Finn RS, Edeline J, Cattan S, Ogasawara S, Palmer D, et al. Pembrolizumab in patients with advanced hepatocellular carcinoma previously treated with sorafenib (KEYNOTE-224): a nonrandomised, open-label phase 2 trial. Lancet Oncol. (2018) 19:940-952. doi: 10.1016/S1470-2045(18)30351-6

17. Finn RS, Ryoo BY, Merle P, Kudo M, Bouattour M, Lim HY, et al. Pembrolizumab as second-Line therapy in patients with advanced hepatocellular carcinoma in kEYNOTE-240: a Randomized, double-Blind, phase III trial. J Clin Oncol. (2020) 38:193-202. doi: 10.1200/JCO.19. 01307

18. Finn RS, Qin S, Ikeda M, Galle PR, Ducreux M, Kim TY, et al. Atezolizumab plus bevacizumab in unresectable hepatocellular carcinoma. $N$ Engl J Med. (2020) 382:1894-905. doi: 10.1056/NEJMoa1915745

19. Crispe IN. Immune tolerance in liver disease. Hepatology. (2014) 60:210917. doi: $10.1002 /$ hep. 27254

20. Robinson MW, Harmon C, O’Farrelly C. Liver immunology and its role in inflammation and homeostasis. Cell Mol Immunol. (2016) 13:26776. doi: $10.1038 / \mathrm{cmi} .2016 .3$

21. Gola A, Dorrington MG, Speranza E, Sala C, Shih RM, Radtke AJ, et al. Commensal-driven immune zonation of the liver promotes host defence. Nature. (2020) doi: 10.1038/s41586-020-2977-2

22. Mossanen JC, Kohlhepp M, Wehr A, Krenkel O, Liepelt A, Roeth AA, et al. CXCR6 inhibits hepatocarcinogenesis by promoting natural killer t- and cD4(+) t-Cell-Dependent control of senescence. Gastroenterology. (2019) 156:1877-89.e1874. doi: 10.1053/j.gastro.2019.01.247

23. Benechet AP, Iannacone M. Determinants of hepatic effector cD8 $(+)$ t cell dynamics. J Hepatol. (2017) 66:228-33. doi: 10.1016/j.jhep.2016.07.011

24. Aizarani N, Saviano A, Sagar Mailly L, Durand S, Herman JS, Pessaux P, et al. A human liver cell atlas reveals heterogeneity and epithelial progenitors. Nature. (2019) 572:199-204. doi: 10.1038/s41586-019-1373-2

25. MacParland SA, Liu JC, Ma XZ, Innes BT, Bartczak AM, Gage BK, et al. Single cell rNA sequencing of human liver reveals distinct intrahepatic macrophage populations. Nat Commun. (2018) 9:4383. doi: 10.1038/s41467-018-06318-7

26. Ramachandran P, Dobie R, Wilson-Kanamori JR, Dora EF, Henderson BEP, Luu NT, et al. Resolving the fibrotic niche of human liver cirrhosis at singlecell level. Nature. (2019) 575:512-518. doi: 10.1038/s41586-019-1631-3

27. Zhang Q, He Y, Luo N, Patel SJ, Han Y, Gao R, et al. Landscape and dynamics of single immune cells in hepatocellular carcinoma. Cell. (2019) 179:829-45.e820. doi: 10.1016/j.cell.2019.10.003

28. Zhang Q, Lou Y, Yang J, Wang J, Feng J, Zhao Y, et al. Integrated multiomic analysis reveals comprehensive tumour heterogeneity and novel immunophenotypic classification in hepatocellular carcinomas. Gut. (2019) 68:2019-31. doi: 10.1136/gutjnl-2019-318912

29. Ma L, Hernandez MO, Zhao Y, Mehta M, Tran B, Kelly M, et al. Tumor cell biodiversity drives microenvironmental reprogramming in liver cancer. Cancer Cell. (2019) 36:418-30.e416. doi: 10.1016/j.ccell.2019.08.007

30. Brunner SF, Roberts ND, Wylie LA, Moore L, Aitken SJ, Davies SE, et al. Somatic mutations and clonal dynamics in healthy and cirrhotic human liver. Nature. (2019) 574:538-42. doi: 10.1038/s41586-019-1670-9

31. Nault JC, Calderaro J, Di Tommaso L, Balabaud C, Zafrani ES, BioulacSage $\mathrm{P}$, et al. Telomerase reverse transcriptase promoter mutation is an early somatic genetic alteration in the transformation of premalignant nodules in hepatocellular carcinoma on cirrhosis. Hepatology. (2014) 60:198392. doi: 10.1002/hep. 27372

32. Cancer Genome Atlas Research Network. Electronic address WBE, Cancer Genome Atlas Research N. Comprehensive and integrative genomic characterization of hepatocellular carcinoma. Cell. (2017) 169:1327-41.e1323. doi: 10.1016/j.cell.2017. 05.046 
33. Chen J, Zaidi S, Rao S, Chen JS, Phan L, Farci P, et al. Analysis of genomes and transcriptomes of hepatocellular carcinomas identifies mutations and gene expression changes in the transforming growth factor-beta pathway. Gastroenterology. (2018) 154:195-210. doi: 10.1053/j.gastro.2017.09.007

34. Chiang DY, Villanueva A, Hoshida Y, Peix J, Newell P, Minguez B, et al. Focal gains of vEGFA and molecular classification of hepatocellular carcinoma. Cancer Res. (2008) 68:6779-88. doi: 10.1158/0008-5472.CAN-08-0742

35. Schulze K, Imbeaud S, Letouze E, Alexandrov LB, Calderaro J, Rebouissou $S$, et al. Exome sequencing of hepatocellular carcinomas identifies new mutational signatures and potential therapeutic targets. Nature genetics. (2015) 47:505-11. doi: 10.1038/ng.3252

36. Zhu M, Lu T, Jia Y, Luo X, Gopal P, Li L, et al. Somatic mutations increase hepatic clonal fitness and regeneration in chronic liver disease. Cell. (2019) 177:608-21.e612. doi: 10.1016/j.cell.2019.03.026

37. Sharma A, Seow JJW, Dutertre CA, Pai R, Bleriot C, Mishra $\mathrm{A}$, et al. Onco-fetal reprogramming of endothelial cells drives immunosuppressive macrophages in hepatocellular carcinoma. Cell. (2020) 183:377-94.e321. doi: 10.1016/j.cell.2020.08.040

38. Sia D, Jiao Y, Martinez-Quetglas I, Kuchuk O, Villacorta-Martin C, Castro de Moura $\mathrm{M}$, et al. Identification of an immune-specific class of hepatocellular carcinoma, based on molecular features. Gastroenterology. (2017) 153:81226. doi: 10.1053/j.gastro.2017.06.007

39. Kurebayashi Y, Ojima H, Tsujikawa H, Kubota N, Maehara J, Abe Y, et al. Landscape of immune microenvironment in hepatocellular carcinoma and its additional impact on histological and molecular classification. Hepatology. (2018) 68:1025-41. doi: 10.1002/hep.29904

40. Rohr-Udilova N, Klinglmuller F, Schulte-Hermann R, Stift J, Herac M, Salzmann $M$, et al. Deviations of the immune cell landscape between healthy liver and hepatocellular carcinoma. Sci Rep. (2018) 8:6220. doi: 10.1038/s41598-018-24437-5

41. Foerster F, Hess M, Gerhold-Ay A, Marquardt JU, Becker D, Galle PR, et al. The immune contexture of hepatocellular carcinoma predicts clinical outcome. Sci Rep. (2018) 8:5351. doi: 10.1038/s41598-018-21937-2

42. Chew V, Lai L, Pan L, Lim CJ, Li J, Ong R, et al. Delineation of an immunosuppressive gradient in hepatocellular carcinoma using highdimensional proteomic and transcriptomic analyses. Proc Natl Acad Sci USA. (2017) 114:E5900-909. doi: 10.1073/pnas.1706559114

43. Itoh S, Yoshizumi T, Yugawa K, Imai D, Yoshiya S, Takeishi K, et al. Impact of immune response on outcomes in hepatocellular carcinoma: association with vascular formation. Hepatology. (2020) doi: 10.1002/hep.31206

44. Lim CJ, Lee YH, Pan L, Lai L, Chua C, Wasser M, et al. Multidimensional analyses reveal distinct immune microenvironment in hepatitis b virus-related hepatocellular carcinoma. Gut. (2019) 68:916-27. doi: 10.1136/gutjnl-2018-316510

45. Blank CU, Haining WN, Held W, Hogan PG, Kallies A, Lugli E, et al. Defining 'T cell exhaustion'. Nature reviews. (2019) 19:66574. doi: 10.1038/s41577-019-0221-9

46. Khan O, Giles JR, McDonald S, Manne S, Ngiow SF, Patel KP, et al. TOX transcriptionally and epigenetically programs $\mathrm{cD} 8(+) \mathrm{t}$ cell exhaustion. Nature. (2019) 571:211-8. doi: 10.1038/s41586-019-1325-x

47. Scott AC, Dundar F, Zumbo P, Chandran SS, Klebanoff CA, Shakiba M, et al. TOX is a critical regulator of tumour-specific t cell differentiation. Nature. (2019) 571:270-4. doi: 10.1038/s41586-019-1324-y

48. Wang $\mathrm{X}, \mathrm{He} \mathrm{Q}$, Shen $\mathrm{H}$, Xia A, Tian $\mathrm{W}, \mathrm{Yu} \mathrm{W}$, et al. TOX promotes the exhaustion of antitumor cD8 $(+) \mathrm{t}$ cells by preventing pD1 degradation in hepatocellular carcinoma. J Hepatol. (2019) 71:73141. doi: 10.1016/j.jhep.2019.05.015

49. Miller BC, Sen DR, Al Abosy R, Bi K, Virkud YV, LaFleur MW, et al. Subsets of exhausted $\mathrm{cD} 8(+) \mathrm{t}$ cells differentially mediate tumor control and respond to checkpoint blockade. Nat Immunol. (2019) 20:32636. doi: 10.1038/s41590-019-0312-6

50. Miller BC, Sen DR, Al Abosy R, Bi K, Virkud YV, LaFleur MW, et al. Author correction: subsets of exhausted cD8 $(+)$ t cells differentially mediate tumor control and respond to checkpoint blockade. Nat Immunol. (2019) 20:1556. doi: 10.1038/s41590-019-0528-5

51. Siddiqui I, Schaeuble K, Chennupati V, Fuertes Marraco SA, CalderonCopete S, Pais Ferreira D, et al. Intratumoral tcf1(+)PD-1(+)CD8(+) T Cells with stem-like properties promote tumor control in response to vaccination and checkpoint blockade immunotherapy. Immunity. (2019) 50:195-211.e110. doi: 10.1016/j.immuni.2018.12.021

52. Sun H, Huang Q, Huang $M$, Wen $H$, Lin $R$, Zheng $M$, et al. Human cD96 correlates to natural killer cell exhaustion and predicts the prognosis of human hepatocellular carcinoma. Hepatology. (2019) 70:16883. doi: 10.1002/hep. 30347

53. Zhou J, Peng H, Li K, Qu K, Wang B, Wu Y, et al. Liver-Resident nK cells control antiviral activity of hepatic T Cells via the pD-1-PD-L1 axis. Immunity. (2019) 50:403-17.e404. doi: 10.1016/j.immuni.2018.12.024

54. Liu Y, Cheng Y, Xu Y, Wang Z, Du X, Li C, et al. Increased expression of programmed cell death protein 1 on $\mathrm{nK}$ cells inhibits nK-cell-mediated antitumor function and indicates poor prognosis in digestive cancers. Oncogene. (2017) 36:6143-53. doi: 10.1038/onc.2017.209

55. Sun $\mathrm{H}, \mathrm{Xu} J$, Huang $\mathrm{Q}$, Huang $\mathrm{M}$, Li K, Qu K, et al. Reduced cD160 expression contributes to impaired nK-cell function and poor clinical outcomes in patients with hCC. Cancer Res. (2018) 78:658193. doi: 10.1158/0008-5472.CAN-18-1049

56. Sun $\mathrm{H}, \mathrm{Xu}$ J, Huang Q, Huang M, Li K, Qu K, et al. Correction: reduced cD160 expression contributes to impaired nK-cell function and poor clinical outcomes in patients with hCC. Cancer Res. (2019) 79:1714. doi: 10.1158/0008-5472.CAN-19-0630

57. Zhang Z, Ma L, Goswami S, Ma J, Zheng B, Duan M, et al. Landscape of infiltrating $b$ cells and their clinical significance in human hepatocellular carcinoma. Oncoimmunology. (2019) 8:e1571388. doi: 10.1080/2162402X.2019.1571388

58. Garnelo M, Tan A, Her Z, Yeong J, Lim CJ, Chen J, et al. Interaction between tumour-infiltrating $b$ cells and $t$ cells controls the progression of hepatocellular carcinoma. Gut. (2017) 66:342-51. doi: 10.1136/gutjnl-2015-310814

59. Sautes-Fridman C, Petitprez F, Calderaro J, Fridman WH. Tertiary lymphoid structures in the era of cancer immunotherapy. Nat Rev Cancer. (2019) 19:307-25. doi: 10.1038/s41568-019-0144-6

60. Finkin S, Yuan D, Stein I, Taniguchi K, Weber A, Unger K, et al. Ectopic lymphoid structures function as microniches for tumor progenitor cells in hepatocellular carcinoma. Nat Immunol. (2015) 16:1235-44. doi: 10.1038/ni.3290

61. Endig J, Buitrago-Molina LE, Marhenke S, Reisinger F, Saborowski A, Schutt J, et al. Dual role of the adaptive immune system in liver injury and hepatocellular carcinoma development. Cancer Cell. (2016) 30:30823. doi: 10.1016/j.ccell.2016.06.009

62. Faggioli F, Palagano E, Di Tommaso L, Donadon M, Marrella V, Recordati $\mathrm{C}$, et al. B lymphocytes limit senescence-driven fibrosis resolution and favor hepatocarcinogenesis in mouse liver injury. Hepatology. (2018) 67:197085. doi: 10.1002/hep. 29636

63. Calderaro J, Petitprez F, Becht E, Laurent A, Hirsch TZ, Rousseau B, et al. Intra-tumoral tertiary lymphoid structures are associated with a low risk of early recurrence of hepatocellular carcinoma. J Hepatol. (2019) 70:5865. doi: 10.1016/j.jhep.2018.09.003

64. Yeung OW, Lo CM, Ling CC, Qi X, Geng W, Li CX, et al. Alternatively activated (M2) macrophages promote tumour growth and invasiveness in hepatocellular carcinoma. J Hepatol. (2015) 62:60716. doi: 10.1016/j.jhep.2014.10.029

65. Yeung OW, Lo CM, Ling CC, Qi X, Geng W, Li CX, et al. Corrigendum to "Alternatively activated (M2) macrophages promote tumour growth and invasiveness in hepatocellular carcinoma" [J hepatol 2015;62:607-616]. J Hepatol. (2016) 64:1461. doi: 10.1016/j.jhep.2016.02.038

66. Chen DP, Ning WR, Jiang ZZ, Peng ZP, Zhu LY, Zhuang SM, et al. Glycolytic activation of peritumoral monocytes fosters immune privilege via the pFKFB3-PD-L1 axis in human hepatocellular carcinoma. J Hepatol. (2019) 71:333-43. doi: 10.1016/j.jhep.2019.04.007

67. Wang D, Li X, Li J, Lu Y, Zhao S, Tang X, et al. APOBEC3B interaction with pRC2 modulates microenvironment to promote hCC progression. Gut. (2019) 68:1846-57. doi: 10.1136/gutjnl-2018-317601

68. Guo X, Zhao Y, Yan H, Yang Y, Shen S, Dai X, et al. Single tumor-initiating cells evade immune clearance by recruiting type iI macrophages. Genes Dev. (2017) 31:247-59. doi: 10.1101/gad.294348.116

69. Dhanasekaran R, Baylot V, Kim M, Kuruvilla S, Bellovin DI, Adeniji N, et al. MYC and twist 1 cooperate to drive metastasis by eliciting crosstalk between 
cancer and innate immunity. Elife. (2020) 9:e50731. doi: 10.7554/eLife. 50731

70. Yan W, Liu X, Ma H, Zhang H, Song X, Gao L, et al. Tim-3 fosters hCC development by enhancing tGF-beta-mediated alternative activation of macrophages. Gut. (2015) 64:1593-604. doi: 10.1136/gutjnl-2014-307671

71. Lanaya H, Natarajan A, Komposch K, Li L, Amberg N, Chen L, et al. EGFR has a tumour-promoting role in liver macrophages during hepatocellular carcinoma formation. Nat Cell Biol. (2014) 16:972-7. doi: 10.1038/ncb3031

72. Wan S, Kuo N, Kryczek I, Zou W, Welling TH. Myeloid cells in hepatocellular carcinoma. Hepatology. (2015) 62:130412. doi: 10.1002/hep.27867

73. Wu Q, Zhou W, Yin S, Zhou Y, Chen T, Qian J, et al. Blocking triggering receptor expressed on myeloid cells-1-Positive tumor-Associated macrophages induced by hypoxia reverses immunosuppression and antiProgrammed cell death ligand 1 resistance in liver cancer. Hepatology. (2019) 70:198-214. doi: 10.1002/hep.30593

74. Molgora M, Esaulova E, Vermi W, Hou J, Chen Y, Luo $\mathrm{J}$, et al. TREM2 modulation remodels the tumor myeloid landscape enhancing anti-PD-1 immunotherapy. Cell. (2020) 182:886-900.e817. doi: 10.1016/j.cell.2020.07.013

75. Malehmir M, Pfister D, Gallage S, Szydlowska M, Inverso D, Kotsiliti E, et al. Platelet gPIbalpha is a mediator and potential interventional target for nASH and subsequent liver cancer. Nat Med. (2019) 25:64155. doi: $10.1055 / \mathrm{s}-0038-1677172$

76. Sitia G, Aiolfi R, Di Lucia P, Mainetti M, Fiocchi A, Mingozzi F, et al. Antiplatelet therapy prevents hepatocellular carcinoma and improves survival in a mouse model of chronic hepatitis B. Proc Natl Acad Sci USA. (2012) 109:E2165-72. doi: 10.1073/pnas.1209182109

77. Zheng C, Zheng L, Yoo JK, Guo H, Zhang Y, Guo X, et al. Landscape of infiltrating T Cells in liver cancer revealed by single-Cell sequencing. Cell. (2017) 169:1342-56.e1316. doi: 10.1016/j.cell.2017.05.035

78. Maier B, Leader AM, Chen ST, Tung N, Chang C, LeBerichel J, et al. Author correction: a conserved dendritic-cell regulatory program limits antitumour immunity. Nature. (2020) 582:E17. doi: 10.1038/s41586-020-2326-5

79. Maier B, Leader AM, Chen ST, Tung N, Chang C, LeBerichel J, et al. A conserved dendritic-cell regulatory program limits antitumour immunity. Nature. (2020) 580:257-62. doi: 10.1038/s41586-020-2134-y

80. Xiao X, Lao XM, Chen MM, Liu RX, Wei Y, Ouyang FZ, et al. PD-1hi identifies a novel regulatory b-cell population in human hepatoma that promotes disease progression. Cancer Discov. (2016) 6:546-59. doi: 10.1158/2159-8290.CD-15-1408

81. Gordon SR, Maute RL, Dulken BW, Hutter G, George BM, McCracken $\mathrm{MN}$, et al. PD-1 expression by tumour-associated macrophages inhibits phagocytosis and tumour immunity. Nature. (2017) 545:495-9. doi: 10.1038/nature22396

82. Meng X, Liu X, Guo X, Jiang S, Chen T, Hu Z, et al. FBXO38 mediates pD-1 ubiquitination and regulates anti-tumour immunity of t cells. Nature. (2018) 564:130-5. doi: 10.1038/s41586-018-0756-0

83. Macek Jilkova Z, Aspord C, Kurma K, Granon A, Sengel C, Sturm $\mathrm{N}$, et al. Immunologic features of patients with advanced hepatocellular carcinoma before and during sorafenib or anti-programmed death1/Programmed death-L1 treatment. Clin Transl Gastroenterol. (2019) 10:e00058. doi: 10.14309/ctg.0000000000000058

84. Ng HHM, Lee RY, Goh S, Tay ISY, Lim X, Lee B, et al. Immunohistochemical scoring of $\mathrm{CD} 38$ in the tumor microenvironment predicts responsiveness to anti-PD-1/PD-L1 immunotherapy in hepatocellular carcinoma. $J$ Immunother Cancer. (2020) 8:987. doi: 10.1136/jitc-2020-000987

85. Tang H, Liang $\mathrm{Y}$, Anders RA, Taube JM, Qiu X, Mulgaonkar A, et al. PD-L1 on host cells is essential for pD-L1 blockade-mediated tumor regression. J Clin Invest. (2018) 128:580-8. doi: 10.1172/ JCI96061

86. Snyder A, Makarov V, Merghoub T, Yuan J, Zaretsky JM, Desrichard A, et al. Genetic basis for clinical response to cTLA-4 blockade in melanoma. $N$ Engl J Med. (2014) 371:2189-99. doi: 10.1056/NEJMoa1406498

87. Rizvi NA, Hellmann MD, Snyder A, Kvistborg P, Makarov V, Havel JJ, et al. Cancer immunology. Mutational landscape determines sensitivity to PD-1 blockade in non-small cell lung cancer. Science. (2015) 348:1248. doi: $10.1126 /$ science.aaa1348
88. McGranahan N, Furness AJ, Rosenthal R, Ramskov S, Lyngaa R, Saini SK, et al. Clonal neoantigens elicit $\mathrm{t}$ cell immunoreactivity and sensitivity to immune checkpoint blockade. Science. (2016) 351:1463-9. doi: 10.1038/s41586-018-0756-0.96

89. DuPage M, Mazumdar C, Schmidt LM, Cheung AF, Jacks T. Expression of tumour-specific antigens underlies cancer immunoediting. Nature. (2012) 482:405-9. doi: 10.1038/nature10803

90. Zaretsky JM, Garcia-Diaz A, Shin DS, Escuin-Ordinas H, Hugo W, Hu-Lieskovan S, et al. Mutations associated with acquired resistance to pD-1 blockade in melanoma. N Engl J Med. (2016) 375:81929. doi: 10.1056/NEJMoa1604958

91. Peng W, Chen JQ, Liu C, Malu S, Creasy C, Tetzlaff MT, et al. Loss of pTEN promotes resistance to T Cells-Mediated immunotherapy. Cancer Discov. (2016) 6:202-16. doi: 10.1158/1538-7445.AM2016-4363

92. Spranger S, Bao R, Gajewski TF. Melanoma-intrinsic beta-catenin signalling prevents anti-tumour immunity. Nature. (2015) 523:2315. doi: $10.1038 /$ nature 14404

93. Harding JJ, Nandakumar S, Armenia J, Khalil DN, Albano M, Ly $\mathrm{M}$, et al. Prospective genotyping of hepatocellular carcinoma: clinical implications of next-Generation sequencing for matching patients to targeted and immune therapies. Clin Cancer Res. (2019) 25:211626. doi: 10.1158/1078-0432.CCR-18-2293

94. Ruiz de Galarreta M, Bresnahan E, Molina-Sanchez P, Lindblad KE, Maier B, Sia $\mathrm{D}$, et al. beta-Catenin activation promotes immune escape and resistance to anti-PD-1 therapy in hepatocellular carcinoma. Cancer Discov. (2019) 9:1124-41. doi: 10.1158/2159-8290.CD-19-0074

95. Okrah K, Tarighat S, Liu B, Koeppen H, Wagle MC, Cheng G, et al. Transcriptomic analysis of hepatocellular carcinoma reveals molecular features of disease progression and tumor immune biology. NPJ Precis Oncol. (2018) 2:25. doi: 10.1038/s41698-018-0068-8

96. Mariathasan S, Turley SJ, Nickles D, Castiglioni A, Yuen K, Wang Y, et al. TGFbeta attenuates tumour response to $\mathrm{pD}-\mathrm{L} 1$ blockade by contributing to exclusion of t cells. Nature. (2018) 554:544-8. doi: 10.1038/nature25501

97. Duffy AG, Ulahannan SV, Makorova-Rusher O, Rahma O, Wedemeyer $\mathrm{H}$, Pratt $\mathrm{D}$, et al. Tremelimumab in combination with ablation in patients with advanced hepatocellular carcinoma. J Hepatol. (2017) 66:54551. doi: 10.1016/j.jhep.2016.10.029

98. Chew V, Lee YH, Pan L, Nasir NJM, Lim CJ, Chua C, et al. Immune activation underlies a sustained clinical response to Yttrium90 radioembolisation in hepatocellular carcinoma. Gut. (2019) 68:33546. doi: 10.1136/gutjnl-2017-315485

99. Zhou G, Sprengers D, Boor PPC, Doukas M, Schutz H, Mancham S, et al. Antibodies against immune checkpoint molecules restore functions of tumor-Infiltrating T Cells in hepatocellular carcinomas. Gastroenterology. (2017) 153:1107-19.e1110. doi: 10.1053/j.gastro.2017.06.017

100. Li J, Lee Y, Li Y, Jiang Y, Lu H, Zang W, et al. Co-inhibitory molecule b7 superfamily member 1 expressed by tumor-Infiltrating myeloid cells induces dysfunction of anti-tumor cD8(+)T Cells. Immunity. (2018) 48:77386.e775. doi: 10.1016/j.immuni.2018.03.018

101. Wang J, Sanmamed MF, Datar I, Su TT, Ji L, Sun J, et al. Fibrinogenlike protein 1 is a major immune inhibitory ligand of lAG-3. Cell. (2019) 176:334-47.e312. doi: 10.1016/j.cell.2018.11.010

102. Zhu Y, Yang J, Xu D, Gao XM, Zhang Z, Hsu JL, et al. Disruption of tumourassociated macrophage trafficking by the osteopontin-induced colonystimulating factor-1 signalling sensitises hepatocellular carcinoma to antiPD-L1 blockade. Gut. (2019) 68:1653-66. doi: 10.1136/gutjnl-2019-318419

103. Tan S, Xu Y, Wang Z, Wang T, Du X, Song X, et al. Tim-3 hampers tumor surveillance of liver-Resident and conventional $\mathrm{nK}$ cells by disrupting pI3K signaling. Cancer Res. (2020) 80:1130-42. doi: 10.1158/0008-5472.CAN-19-2332

104. Li X, Yao $\mathrm{W}$, Yuan $\mathrm{Y}$, Chen $\mathrm{P}, \mathrm{Li} \mathrm{B}, \mathrm{Li}$ J, et al. Targeting of tumour-infiltrating macrophages via cCL2/CCR2 signalling as a therapeutic strategy against hepatocellular carcinoma. Gut. (2017) 66:157-67. doi: 10.1136/gutjnl-2015-310514

105. Eggert T, Wolter K, Ji J, Ma C, Yevsa T, Klotz S, et al. Distinct functions of senescence-Associated immune responses in liver tumor surveillance and tumor progression. Cancer Cell. (2016) 30:533-47. doi: 10.1016/j.ccell.2016.09.003 
106. Xu G, Feng D, Yao Y, Li P, Sun H, Yang H, et al. Listeria-based hepatocellular carcinoma vaccine facilitates anti-PD-1 therapy by regulating macrophage polarization. Oncogene. (2020) 39:1429-44. doi: 10.1038/s41388-0191072-3

107. Shigeta K, Datta M, Hato T, Kitahara S, Chen IX, Matsui A, et al. Dual programmed death receptor-1 and vascular endothelial growth factor receptor-2 blockade promotes vascular normalization and enhances antitumor immune responses in hepatocellular carcinoma. Hepatology. (2020) 71:1247-61. doi: 10.1002/hep.30889

108. Hollande C, Boussier J, Ziai J, Nozawa T, Bondet V, Phung W, et al. Inhibition of the dipeptidyl peptidase dPP4 (CD26) reveals iL-33-dependent eosinophil-mediated control of tumor growth. Nat Immunol. (2019) 20:25764. doi: 10.1038/s41590-019-0321-5

109. Vollmer CM, Jr Eilber FC, Butterfield LH, Ribas A, Dissette VB, Koh A, et al. Alpha-fetoprotein-specific genetic immunotherapy for hepatocellular carcinoma. Cancer Res. (1999) 59:3064-7.

110. Thimme R, Neagu M, Boettler T, Neumann-Haefelin C, Kersting N, Geissler $\mathrm{M}$, et al. Comprehensive analysis of the alpha-fetoprotein-specific cD8 $+\mathrm{t}$ cell responses in patients with hepatocellular carcinoma. Hepatology. (2008) 48:1821-33. doi: 10.1002/hep.22535

111. Zhu W, Peng Y, Wang L, Hong Y, Jiang X, Li Q, et al. Identification of alpha-fetoprotein-specific t-cell receptors for hepatocellular carcinoma immunotherapy. Hepatology. (2018) 68:574-89. doi: 10.1002/hep.29844

112. Mizukoshi E, Nakamoto Y, Marukawa Y, Arai K, Yamashita T, Tsuji H, et al. Cytotoxic t cell responses to human telomerase reverse transcriptase in patients with hepatocellular carcinoma. Hepatology. (2006) 43:128494. doi: 10.1002/hep. 21203

113. Nakatsura T, Yoshitake Y, Senju S, Monji M, Komori H, Motomura Y, et al. Glypican-3, overexpressed specifically in human hepatocellular carcinoma, is a novel tumor marker. Biochem Biophys Res Commun. (2003) 306:1625. doi: 10.1016/S0006-291X(03)00908-2

114. Capurro M, Wanless IR, Sherman M, Deboer G, Shi W, Miyoshi E, et al. Glypican-3: a novel serum and histochemical marker for hepatocellular carcinoma. Gastroenterology. (2003) 125:89-97. doi: 10.1016/S0016-5085(03)00689-9

115. Komori H, Nakatsura T, Senju S, Yoshitake Y, Motomura Y, Ikuta Y, et al. Identification of hLA-A2- or hLA-A24-restricted cTL epitopes possibly useful for glypican-3-specific immunotherapy of hepatocellular carcinoma. Clin Cancer Res. (2006) 12:2689-97. doi: 10.1158/1078-0432.CCR-05-2267

116. Cicinnati VR, Zhang X, Yu Z, Ferencik S, Schmitz KJ, Dworacki G, et al. Increased frequencies of $\mathrm{cD} 8+\mathrm{t}$ lymphocytes recognizing wild-type p53derived epitopes in peripheral blood correlate with presence of epitope loss tumor variants in patients with hepatocellular carcinoma. Int J Cancer. (2006) 119:2851-60. doi: 10.1002/ijc.22251

117. Zerbini A, Pilli M, Soliani P, Ziegler S, Pelosi G, Orlandini A, et al. Ex vivo characterization of tumor-derived melanoma antigen encoding genespecific cD8+cells in patients with hepatocellular carcinoma. J Hepatol. (2004) 40:102-9. doi: 10.1016/S0168-8278(03)00484-7

118. Kaji K, Mizukoshi E, Yamashita T, Arai K, Sunagozaka H, Fushimi K, et al. Cellular immune responses for squamous cell carcinoma antigen recognized by T Cells 3 in patients with hepatocellular carcinoma. PLoS ONE. (2017) 12:e0170291. doi: 10.1371/journal.pone.0170291
119. Korangy F, Ormandy LA, Bleck JS, Klempnauer J, Wilkens L, Manns MP, et al. Spontaneous tumor-specific humoral and cellular immune responses to nY-ESO-1 in hepatocellular carcinoma. Clin Cancer Res. (2004) 10:433241. doi: 10.1158/1078-0432.CCR-04-0181

120. Thura M, Al-Aidaroos AQ, Gupta A, Chee CE, Lee SC, Hui $\mathrm{KM}$, et al. PRL3-zumab as an immunotherapy to inhibit tumors expressing pRL3 oncoprotein. Nat Commun. (2019) 10:2484. doi: 10.1038/s41467-019-10127-x

121. Shirakawa H, Suzuki H, Shimomura M, Kojima M, Gotohda N, Takahashi S, et al. Glypican-3 expression is correlated with poor prognosis in hepatocellular carcinoma. Cancer Sci. (2009) 100:14037. doi: 10.1111/j.1349-7006.2009.01206.x

122. Abou-Alfa GK, Puig O, Daniele B, Kudo M, Merle P, Park JW, et al. Randomized phase II placebo controlled study of codrituzumab in previously treated patients with advanced hepatocellular carcinoma. J Hepatol. (2016) 65:289-95. doi: 10.1016/j.jhep.2016.04.004

123. Hashimoto K. A phase I dose escalation and cohort expansion study of T-cell redirecting bispecific antibody against glypican 3 in patients with advanced solid tumors. J Clin Oncol. (2016) 34:2592. doi: 10.1200/JCO.2016.34.15_suppl.TPS2592

124. Jiang Z, Jiang X, Chen S, Lai Y, Wei X, Li B, et al. Anti-GPC3CAR $T$ Cells suppress the growth of tumor cells in patient-Derived xenografts of hepatocellular carcinoma. Front Immunol. (2016) 7:690. doi: 10.3389/fimmu.2016.00690

125. Fu Y, Urban DJ, Nani RR, Zhang YF, Li N, Fu H, et al. Glypican-3-Specific antibody drug conjugates targeting hepatocellular carcinoma. Hepatology. (2019) 70:563-76. doi: 10.1002/hep.30326

126. Wu Q, Pi L, Le Trinh T, Zuo C, Xia M, Jiao Y, et al. A novel vaccine targeting glypican-3 as a treatment for hepatocellular carcinoma. Mol Ther. (2017) 25:2299-308. doi: 10.1016/j.ymthe.2017.08.005

127. Li D, Li N, Zhang YF, Fu H, Feng M, Schneider D, et al. Persistent polyfunctional chimeric antigen receptor $\mathrm{T}$ Cells that target glypican 3 eliminate orthotopic hepatocellular carcinomas in mice. Gastroenterology. (2020) 158:2250-65.e2220. doi: 10.1053/j.gastro.2020.02.011

128. Moehler M, Heo J, Lee HC, Tak WY, Chao Y, Paik SW, et al. Vaccinia-based oncolytic immunotherapy pexastimogene devacirepvec in patients with advanced hepatocellular carcinoma after sorafenib failure: a randomized multicenter phase IIb trial (TRAVERSE). Oncoimmunology. (2019) 8:1615817. doi: 10.1080/2162402X.2019.16 15817

Conflict of Interest: The authors declare that the research was conducted in the absence of any commercial or financial relationships that could be construed as a potential conflict of interest.

Copyright (C) 2021 Giraud, Chalopin, Blanc and Saleh. This is an open-access article distributed under the terms of the Creative Commons Attribution License (CC BY). The use, distribution or reproduction in other forums is permitted, provided the original author(s) and the copyright owner(s) are credited and that the original publication in this journal is cited, in accordance with accepted academic practice. No use, distribution or reproduction is permitted which does not comply with these terms. 